Article

\title{
Is There a Link between Zinc Intake and Status with Plasma Fatty Acid Profile and Desaturase Activities in Dyslipidemic Subjects?
}

\author{
Marija Knez ${ }^{1, *}$, Ana Pantovic ${ }^{1}$, Milica Zekovic ${ }^{1}{ }^{\circledR}$, Zoran Pavlovic $^{2}$, Maria Glibetic ${ }^{1}$ and \\ Manja Zec ${ }^{1}$ (D) \\ 1 Centre of Research Excellence in Nutrition and Metabolism, Institute for Medical Research, \\ University of Belgrade, 11000 Belgrade, Serbia; jelenkovicana5@gmail.com (A.P.); \\ zekovicmilica@gmail.com (M.Z.); mglibetic@gmail.com (M.G.); manjazecimr@gmail.com (M.Z.) \\ 2 Institute for Public Health Pozarevac, Jovana Serbanovica 14, 12000 Pozarevac, Serbia; \\ zpavlovicpo@yahoo.com \\ * Correspondence: marijaknez186@gmail.com; Tel.: +011-3031997
}

Received: 14 November 2019; Accepted: 24 December 2019; Published: 28 December 2019

\begin{abstract}
The prevalence of obesity and dyslipidemia has increased worldwide. The role of trace elements in the pathogenesis of these conditions is not well understood. This study examines the relationship between dietary zinc $(\mathrm{Zn})$ intake and plasma concentrations of $\mathrm{Zn}$, copper $(\mathrm{Cu})$ and iron $(\mathrm{Fe})$ with lipid profile indicators, fatty acid composition in plasma phospholipids and desaturase enzyme activities in a dyslipidemic population. The role of the newly proposed biomarker of $\mathrm{Zn}$ status, the linoleic:dihomo-gama-linolenic acid (LA:DGLA) ratio, in predicting Zn status of dyslipidemic subjects has been explored. The study included 27 dyslipidemic adults, 39-72 years old. Trace elements were determined using atomic absorption spectrometry and fatty acid composition by a liquid gas chromatography. Desaturase activities were calculated from product-precursor fatty acid ratios. Dietary data were obtained using $24 \mathrm{~h}$ recall questionnaires. Insufficient dietary intake of $\mathrm{Zn}$, low plasma $\mathrm{Zn}$ concentrations and an altered $\mathrm{Cu}: \mathrm{Zn}$ ratio is related to modified fatty acid profile in subjects with dyslipidemia. Plasma Zn status was associated with obesity. There was no correlation between dietary $\mathrm{Zn}$ intake and plasma $\mathrm{Zn}$ status. The LA:DGLA ratio was inversely linked to dietary $\mathrm{Zn}$ intake. $\mathrm{Cu}$, in addition to $\mathrm{Zn}$, may directly or indirectly, affect the activity of desaturase enzymes.
\end{abstract}

Keywords: Zn deficiency; Zn status; fatty acids; dyslipidemia; desaturases; dietary Zn intake

\section{Introduction}

The number of people affected by obesity and dyslipidemia has increased significantly during the last two decades, largely attributed to the changes in dietary and lifestyle habits. Sixty-five percent of the world's population live in countries where overweight and obesity harm more people than malnutrition [1]. According to the World Health organization (WHO) the worldwide obesity rates have nearly tripled since 1975 [1]. In addition, the incidence of obesity related diseases (i.e., hypertension, dyslipidemia, metabolic syndrome) also increases [1,2]. Dyslipidemia is described as the presence of non-optimal blood lipids levels. People with dyslipidemia have either increased concentrations of triglycerides or low-density lipoprotein cholesterol (LDL-C), or decreased levels of high-density lipoprotein cholesterol (HDL-C) [3,4]. Raised cholesterol levels cause on average 2.6 million deaths and 29.7 million disability adjusted life years (DALYS) [1]. Dyslipidemia is one of the major contributors to atherosclerotic and ischemic heart disease $[1,5,6]$. In 2008, the prevalence of raised blood lipid levels among adults globally was 39\% [1] and WHO identified that the occurrence was the highest in the 
region of Europe (54\% for both sexes). Successful treatment of dyslipidemia significantly reduces morbidity and mortality from cardiovascular diseases [7]. Basically $10 \%$ reduction in serum lipid levels has been reported to result in a 50\% reduction in heart disease within 5 years [1].

Trace elements have crucial roles in metabolism, growth, immunological and neurological functions [8-10]. Zinc (Zn) is required for an adequate activity of more than 300 enzymes involved in protein synthesis, fatty acid metabolism, reproduction and oxidative clearance [11]. Iron (Fe) is needed for proper oxygen transport, while copper $(\mathrm{Cu})$ is important for the oxido-reduction and detoxification and is involved in growth, development of cellular elements of arterial walls, lipoprotein metabolism and immune function $[9,12,13]$. The concentrations of serum/plasma minerals $\mathrm{Zn}, \mathrm{Cu}$ and Fe are associated with the development of chronic diseases $[10,14,15]$. Deficiency in microelements leads to an increase in fat deposition and obesity [16]. Hypoferremia is often seen in people suffering from hypertension and plasma $\mathrm{Zn}$ concentrations have been directly correlated with total cholesterol and LDL-C levels $[15,17]$. $\mathrm{Zn}, \mathrm{Cu}$ and Fe plasma levels are related to the extent of myocardial damage [18]. Epidemiological studies show a direct correlation between low plasma $\mathrm{Zn}$ and $\mathrm{Fe}$ concentrations and increased risk of cardiovascular diseases [19]. Elevated plasma levels of Cu were reported in patients with coronary artery disease [20]. Although deficiencies of trace elements may alter metabolism of lipids and lipoproteins, the mechanism of their action is not yet completely understood. The fatty acid (FA) composition in serum phospholipids remains a reliable biomarker of long-term fat intake [21] and it can predict the development of metabolic and cardiovascular diseases [22]. It shows the endogenous FA metabolism, regulated by desaturase enzymes $(\Delta 5, \Delta 6$ and $\Delta 9)$. Desaturase enzymes convert dietary FAs to long-chain omega 3 and omega 6-polyunsaturated fatty acids (PUFAs), the latter with demonstrated role in the prevention of dyslipidemia and metabolic syndrome $[23,24]$. Serum FA composition also predicts long-term development of dyslipidemia and metabolic syndrome [25-27]. Furthermore, alterations in desaturase activities were seen in subjects who are obese and insulin resistant $[28,29]$. Trace elements have a role in FA metabolism. Zn is a cofactor for desaturases and elongases in endogenous FA synthesis [30-35], so the alterations in plasma levels of $\mathrm{Zn}$ possibly influence the activities of these enzymes and consequently the regulation of FA metabolism. Serum concentrations of $\mathrm{Zn}$ and Fe correlated with serum PUFA concentrations and activities of certain desaturases [36-38]. However, the role of micronutrients in dyslipidemia warrants further research. Linoleic/dihomo-gama-linolenic acid (LA:DGLA) ratio is linked with dietary $\mathrm{Zn}$ intakes and this ratio has been proposed as a novel biomarker of $\mathrm{Zn}$ status in both animals and humans $[32,33,35,39]$. The predictive potential of this ratio has not been investigated in dyslipidemic subjects so far. The primary aim of this study was to examine the relationship between plasma concentrations of $\mathrm{Zn}, \mathrm{Cu}$, and $\mathrm{Fe}$ with long-chain individual FAs, FAs belonging to de novo lipogenesis pathway and estimated desaturase activities in a group of dyslipidemic adults. The relationship of the microelements with anthropometric and lipid profile parameters was assessed. The LA:DGLA ratio, an emerging biomarker of $\mathrm{Zn}$ status, has been additionally examined for potential correlations with clinical parameters. Finally, the contribution of particular food groups to the relationships between trace elements and fat metabolism was evaluated.

\section{Materials and Methods}

\subsection{Study Population}

This cross-sectional study is the part of a larger nutritional intervention study registered as NCT03227497 (ClinicalTrials.gov). Eligible subjects were non-smoking adults at moderate cardiovascular risk, the latter defined as the presence of at least one of the following: increased body mass index $\left(\mathrm{BMI}=25-30 \mathrm{~kg} / \mathrm{m}^{2}\right.$ ), central obesity (waist circumference $\geq 80 \mathrm{~cm}$ for women and $\geq 94 \mathrm{~cm}$ for men), and high normal blood pressure (systolic/diastolic blood pressure (SBP/DBP) $>120 / 80$, $\leq 139 / 89 \mathrm{~mm} \mathrm{Hg}$ ). Dyslipidemia was defined according to the guideline of the US National Cholesterol Education Program Adult Treatment Panel III (NCEP-ATP III) [7,40]. The exclusion criteria were 
the presence of chronic disease, self-reported allergy to any type of nuts, pregnancy, lactation, blood donation 16 weeks before the start of the study and a parallel participation in another clinical trial.

Recruitment of the subjects was performed via newspaper advertisement or word of mouth. For the purposes of the current sub-study, we selected subjects with disturbed levels of serum lipids, as seen in either: elevated serum total cholesterol ( $\geq 5.2 \mathrm{mmol} / \mathrm{L})$, and/or elevated low-density lipoprotein cholesterol (LDL-C $\geq 3.4 \mathrm{mmol} / \mathrm{L}$ ) and/or elevated serum triacylglycerides (TG $\geq 1.7 \mathrm{mmol} / \mathrm{L}$ ) and/or decreased high-density lipoprotein cholesterol (HDL-C $\leq 1.04 \mathrm{mmol} / \mathrm{L}$ and 1.29 for men and women, respectively). Finally, we were left with 27 dyslipidemic subjects of both genders, who were examined in the current study to assess the relationship between micronutrient intake and status with fat metabolism.

\subsection{Ethical Considerations}

All subjects went through the informed consent process, both verbal and written. The study protocol was approved by the Institute for Medical Research, University of Belgrade, Belgrade, Serbia, Ethics Committee Approval, No: EO120/2017. The study was conducted in agreement with the ethical guidelines on biomedical research on human subjects of The Code of Ethics of the World Medical Association's Declaration of Helsinki (1964) and its further amendments [41]. This study forms a part of the randomized clinical trial registered as NCT03227497 (ClinicalTrials.gov).

\subsection{Blood Samples Collection and Analysis}

Blood samples were collected after an overnight fast ( $>10 \mathrm{~h}$ fasting) between $7-8$ a.m. by venepuncture of the antecubital vein. Tubes with ethylenediaminetetraacetic acid as anticoagulant were used, and all of them were free of trace elements. Lipid status and concentration of glucose, along with other routine biochemical parameters were determined from serum samples on the same day they were collected. For this purpose, a clinical chemistry analyzer Cobas c111 was used (Roche Diagnostics, Basel, Switzerland) and Roche Diagnostics' kits according to the manufacturer's instructions.

\subsection{Anthropometric Measurements}

Anthropometric variables, height and weight, were measured to the nearest $0.1 \mathrm{~cm}$ and $0.1 \mathrm{~kg}$, respectively. The weight and percent of fat mass in the body composition of participants were measured using a TANITA UM072 balance (TANITA Health Equipment H.K. LTD, Hong Kong, China). The BMI was calculated as the ratio of weight $(\mathrm{kg})$ to height squared $\left(\mathrm{m}^{2}\right)$. BMI was used to assess the prevalence of overweight (25-29.9 kg/m²) and obesity $\left(\geq 30 \mathrm{~kg} / \mathrm{m}^{2}\right)$ according to WHO criteria [1].

\subsection{Assessment of Dietary Zn Intake}

Dietary intake assessment was based on two $24 \mathrm{~h}$ recalls collected for non-consecutive days, one working day and one weekend day, to capture the intra-individual food consumption variability. Nutritional evaluation was performed during pre-scheduled participants' visit to the study center within in-depth interviews conducted by trained researchers. Recalls were administered according to multiple-pass approach with standardized protocol, interview structure, and probing questions. To facilitate the evaluation of food servings and improve accuracy of reporting, participants were prompted with validated two-dimensional portion size estimation aid i.e., booklet comprising photograph-series illustrating a range of reference portions for 135 items (both simple foods and recipes) commonly consumed in the Balkan region [42]. In conjunction with the photographic atlas, household measures, package/labelling data, the standard serving size information and natural units were used to quantify the amount of food consumed.

Dietary questionnaires were coded and analyzed using Diet Assess \& Plan, an advanced nutritional software tool, evaluated by European Food Safety Authority (EFSA) and successfully used in various national/regional surveys and international projects $[43,44]$. The consumption data was converted to nutrient intake estimates according to the Serbian Food Composition Database, compiled and managed in accordance with the international guidelines and embedded in the European Food Information 
Resource AISBL (EuroFIR AISBL) platform [45]. Nutrient intake calculation was performed by multiplying the estimated gram weight of the consumed food with the nutrient contents per gram from the food composition table. The average daily intakes of energy, macronutrients, trace elements, FAs, and the main food groups were derived from a mean of two administrations of the questionnaire.

\subsection{Fatty Acid Determination and Estimation of Desaturase Activity}

Fatty acid concentrations were determined by gas chromatography (GC). By use of chloroform-methanol mixture (2:1), total plasma lipids were extracted according to method of Folch et al. [46]. To prevent lipid peroxidation, 2,6-di-tert-butyl-4-methylphenol $(10 \mathrm{mg} / 100 \mathrm{~mL})$ were added to the mixture of solvents. Further on, phospholipids were separated from total lipids on silica thin-layer chromatography plate, on a mixture of petroleum ether, diethyl ether, and glacial acetic acid (87:12:1) used as a solvent system. Following the previously described procedure [47] with slight modifications [48] FA methyl-esters were further obtained by direct trans-methylation. Obtained FA methyl-esters were analyzed by gas chromatography on Shimadzu chromatograph GC 2014, Tokyo, Japan equipped with a flame ionization detector and a Rtx 2330 fused silica gel capillary column $(60 \mathrm{~m} \times 0.25 \mathrm{~mm}$ id $\times 0.2 \mu \mathrm{m}$ film thickness) (Restek Co., Bellefonte, PA, USA) according to method by Veselinovic et al. [48]. For the purposes of current study oleic acid (18:1 n-9), alpha-linolenic acid (LNA, 18:3n-3), linoleic acid (LA, 18:2 $n-6$ ), dihomo- $\gamma$-linolenic acid (DGLA, 20:3n-6), arachidonic acid (ARA, 20:4n-6), adrenic acid (AA, 22:4n-6), eicosapentaenoic acid (EPA, 20:5n-3), docosapentaenoic acid (DPA, 22:5n-3), and docosahexaenoic acid (DHA, 22:6n-3) were identified. The peak retention times were compared with certified calibration mixtures (PUFA-2, Supelco, Bellefonte, PA, USA, and 37 FAMEs mix, Sigma Chemical Co., St. Louis, MO, USA). The amounts of individual FA are presented as the relative percentage of the total $(100 \%)$ FA pool. The desaturase activities were estimated as precursor-to-product ratios of individual FAs as follows: the ratio AA/DGLA (20:4 $n-6 / 20: 3 n-6)$ for delta 5 desaturase, GLA/AA (20:3n-6/18:2 $n-6)$ for delta 6 desaturase and 16:1 n-7/16:0 ratio for delta 9 desaturase [49].

\subsection{Mineral Analysis}

The analysis of plasma mineral concentrations was conducted using flame atomic absorption spectrometry on a Varian SpectrAA-10 (Varian, Inc., Mulgrave, Victoria, Australia) according to the method described by Jian Xin [50]. The reference range used for plasma $\mathrm{Zn}$ concentration was $0.7-1.5 \mathrm{mg} / \mathrm{L} ; 0.5-1.5 \mathrm{mg} / \mathrm{L}$ was used for Fe and $0.7-1.4 \mathrm{mg} / \mathrm{L}$ for $\mathrm{Cu}$ [51-53]. To verify the accuracy of the method, two control serums with certified concentrations of zinc, cooper and iron, (ClinChek-Control, Recipe Chemical + Instruments $\mathrm{GmbH}$; catalogue number 8882) were analyzed. Method performance was monitored by analysis of the same control serums within each of the series. The obtained results agreed with the certified values.

\subsection{Statistical Analysis}

The normality of the data was assessed with the Shapiro-Wilk test. Normally distributed data are presented as mean (standard deviation) (SD) and non-normally scattered as median [interquartile range]. The variability in the baseline parameters was determined depending on the plasma $\mathrm{Zn}$ status, stratified according to $\mathrm{Zn}$ tertiles. The total number of participants when divided according to tertiles was 23 .

The difference between the tertiles in the selected variables was explored with one-way analysis of variance test for normally distributed data, and with Kruskal Wallis test for non-normally distributed data. To explore potential relationships between the study outcomes, the correlation analyses were employed. For normally distributed data, Pearson's correlation tests were used, while for non-normally distributed data the corresponding non-parametric-Spearman's correlation test was employed. To explore potential confounding effects, partial correlation tests were used, with addition of the following variables: age, gender, plasma $\mathrm{Zn}$ status. All analysis was performed in SPSS version 23.0 (BM Corp., Armonk, NY, USA), with a significance threshold set at 0.05. Graphical presentations were generated in RStudio (2019) (Version 1.2.1335, Boston, MA, USA) [54]. 


\section{Results}

\subsection{Baseline Characteristics of Study Participants}

Table 1 illustrates the baseline characteristics of study participants based on the tertiles of plasma $\mathrm{Zn}$ concentrations. The mean age of the participants was 56 with values ranging from 39-72. Forty-eight percent of this study population was overweight and 22\% obese. Values for BMI fluctuated from 18.4 to 39.6 , with a mean value of $28.2 \mathrm{~kg} / \mathrm{m}^{2}$. Fifty-two percent of people had a waist:hip ratio above 0.86 . The percentage of study subjects with high total cholesterol and high LDL-C was $88 \%$, while $30 \%$ of the complete sample was with low levels of HDL-C. Increased level of TG, in addition to high LDL-C and low HDL-C, was seen in $18.5 \%$ of participants. The mean fasting blood glucose (FPG) was $5.17 \mathrm{nmol} / \mathrm{L}$, with $25 \%$ of people with glucose levels above the reference value of $5.84 \mathrm{nmol} / \mathrm{L}$. Fifty-seven percent of subjects had elevated blood pressure (reference range 130/80).

Table 1. Baseline characteristics of study participants.

\begin{tabular}{|c|c|c|c|c|c|}
\hline & $\begin{array}{l}\text { Whole Sample } \\
\quad(n=27)\end{array}$ & $\begin{array}{c}\text { 1st } \mathrm{Zn} \text { Tertile } \\
(n=8)\end{array}$ & $\begin{array}{c}\text { 2nd Zn Tertile } \\
\quad(n=7)\end{array}$ & $\begin{array}{c}\text { 3rd Zn Tertile } \\
\quad(n=8)\end{array}$ & $p$-Value \\
\hline \multicolumn{6}{|l|}{ Clinical Parameters } \\
\hline Age, Years & $57.00[16.00]$ & $59.50[15.00]$ & $63.00[24.00]$ & $53.00[14.00]$ & $p=0.781$ \\
\hline Weight, Kg & $77.50[31.30]$ & $68.65[18.37]$ & $76.4[22.70]$ & $95.90[21.10]$ & $p=0.001$ \\
\hline BMI, $\mathrm{Kg} / \mathrm{M}^{2}$ & $27.10[8.30]$ & $24.85[8.97]$ & $26.60[3.80]$ & $34.10[9.82]$ & $p=0.009$ \\
\hline Plasma $\mathrm{Zn}, \mathrm{Mg} / \mathrm{L}$ & $0.75[0.14]$ & $0.64[0.09]$ & $0.75[0.05]$ & $0.86[0.08]$ & $p<0.001$ \\
\hline Plasma Fe, Mg/L & $0.85[0.65]$ & $0.82[0.23]$ & $1.10[0.91]$ & $0.90[0.76]$ & $p=0.328$ \\
\hline Plasma $\mathrm{Cu}, \mathrm{Mg} / \mathrm{L}$ & $0.98[0.16]$ & $1.01[0.06]$ & $0.94[0.11]$ & $0.95[0.18]$ & $p=0.289$ \\
\hline $\mathrm{Cu}: \mathrm{Zn}$ & $1.27[0.39]$ & $1.60[0.36]$ & $1.26[0.10]$ & $1.05[0.31]$ & $p<0.001$ \\
\hline Total Cholesterol, Mmol/L & $5.87[1.26]$ & $5.87[0.67]$ & $6.65[1.29]$ & $5.95[0.96]$ & $p=0.383$ \\
\hline HDL-C, Mmol/L & $1.41[0.64]$ & $1.69[0.35]$ & $1.28[0.60]$ & $1.22[0.59]$ & $p=0.318$ \\
\hline LDL-C, Mmol/L & $3.95[0.79]$ & $3.59[0.60]$ & $4.33[1.00]$ & $3.83[0.58]$ & $p=0.076$ \\
\hline $\mathrm{TG}, \mathrm{Mmol} / \mathrm{L}$ & 1.20 [0.69] & $1.00[0.33]$ & $1.56[0.49]$ & $1.37[0.77]$ & $p=0.928$ \\
\hline FPG, Nmol/L & $5.17[0.98]$ & $4.96[0.57]$ & $5.76[1.11]$ & $5.53[1.16]$ & $p=0.166$ \\
\hline Systolic BP, MmHg & $131.00[32.00]$ & $137.00[51.75]$ & $120.00[29.00]$ & 136.50 [13.00] & $p=0.295$ \\
\hline Diastolic BP, MmHg & $81.00[22.00]$ & 76.50 [17.75] & 70.00 [19.00] & $90.50[14.50]$ & $p=0.075$ \\
\hline \multicolumn{6}{|c|}{ Fatty Acids in Plasma Phospholipids\% } \\
\hline $18: 1 n-9$ & $8.11[1.89]$ & 8.04 [1.27] & $8.12[2.40]$ & 8.02 [1.59] & $p=0.951$ \\
\hline $18: 2 n-6$ & $24.01[5.09]$ & $26.62[5.51]$ & $25.69[6.79]$ & $21.99[4.10]$ & $p=0.385$ \\
\hline $18: 3 n-3$ & $0.08[0.068]$ & $0.11[0.05]$ & $0.07[0.05]$ & $0.08[0.08]$ & $p=0.214$ \\
\hline $20: 3 n-6$ & 2.83 [1.28] & 2.71 [1.17] & 2.83 [1.29] & $2.71[1.32]$ & $p=0.958$ \\
\hline $20: 4 n-6$ & $11.67[2.84]$ & $10.86[4.90]$ & $11.58[2.72]$ & $12.27[1.03]$ & $p=0.330$ \\
\hline $20: 5 n-3$ & $0.27[0.21]$ & $0.27[0.57]$ & $0.23[0.09]$ & $0.42[0.16]$ & $p=0.239$ \\
\hline $22: 4 n-6$ & $0.36[0.17]$ & $0.33[0.22]$ & $0.40[0.16]$ & $0.37[0.15]$ & $p=0.775$ \\
\hline $22: 5 n-3$ & $0.55[0.15]$ & $0.27[0.57]$ & $0.50[0.16]$ & $0.56[0.19]$ & $p=0.436$ \\
\hline $22: 6 n-3$ & $2.49[1.42]$ & $2.44[1.95]$ & $2.40[0.17]$ & 3.32 [1.33] & $p=0.403$ \\
\hline$\Delta 5$-Desaturase & $3.68[1.80]$ & $3.47[0.61]$ & $3.82[1.53]$ & $4.52[2.88]$ & $p=0.406$ \\
\hline$\Delta 6$-Desaturase & 0.009 [0.003] & $0.007[0.005]$ & $0.009[0.003]$ & $0.009[0.003]$ & $p=0.866$ \\
\hline LA: DGLA & $8.81[3.85]$ & $9.45[6.18]$ & $8.93[3.94]$ & $8.47[2.94]$ & $p=0.856$ \\
\hline$\Delta 9$-Desaturase & $0.14[0.01]$ & $0.013[0.004]$ & $0.014[0.010]$ & $0.012[0.005]$ & $p=0.145$ \\
\hline
\end{tabular}

Data are presented as median [interquartile range] in complete sample and according to the tertiles of plasma zinc levels. Bolded $p$-values represent the results of one-way ANOVA or Kruskal Wallis test on significant differences between the $\mathrm{Zn}$ tertiles. Abbreviations: BMI—body mass index; HDL-C—high-density lipoprotein cholesterol; LDL-C-low-density lipoprotein cholesterol; Body Fat\%-body fat percentage; TG-triglycerides; FPG-fasting plasma glucose; BP-blood pressure; LA: DGLA-linolenic acid/dihomo-gama-linolenic acid ratio. 
The average plasma $\mathrm{Zn}$ concentration was $0.75 \pm 0.1 \mathrm{mg} / \mathrm{L}$ with $26 \%$ of participants having plasma Zn concentrations below $0.7 \mathrm{mg} / \mathrm{L}$. More than $50 \%$ of study subjects were with plasma Zn levels below $0.75 \mathrm{mg} / \mathrm{L}$, with the highest concentration of $1.03 \mathrm{mg} / \mathrm{L}$ being measured. The average Cu:Zn ratio was 1.3. The levels of $\mathrm{Cu}$ and Fe were within the recommended reference ranges for healthy people. The percentage of individual FAs and desaturase enzyme activities are presented in Table 1. The plasma levels of $\mathrm{Zn}$ increased with higher weight and BMI. No differences between the groups were seen for plasma concentrations of either Fe or $\mathrm{Cu}$. There was a statistically significant difference in the $\mathrm{Cu}: \mathrm{Zn}$ ratio between the tertile groups, with the highest ratio observed in the 1 st $\mathrm{Zn}$ tertile. No statistically relevant relations were shown between the groups for any of the lipid profile indicators. Concentrations of the individual FAs did not differ between the $\mathrm{Zn}$ formed groups $(p>0.05)$.

\subsection{Associations between Plasma Zn, Fe, and Cu Status with Anthropometrical and Biochemical Measures}

There was a direct correlation between $\mathrm{Zn}$ and BMI, and a significant inverse relation between the $\mathrm{Cu}: \mathrm{Zn}$ ratio and BMI. The relationships remained in the age and gender-adjusted model: Zn correlated directly $(\mathrm{r}=0.536, p=0.02)$, while $\mathrm{Cu}: \mathrm{Zn}$ ratio inversely $(\mathrm{r}=-0.488, p=0.02)$ with BMI. There was an inverse relationship between the $\mathrm{Cu}: \mathrm{Zn}$ ratio with Cho/HDL, LDL/HDL and non-HDL/HDL (Table 2). $\mathrm{Fe}$ and $\mathrm{Cu}$ were not correlated with any of the biochemical parameters measured in this study (Table 2).

No statistically significant correlations were observed between the plasma concentrations of different minerals $(p>0.05)$. There is no statistically relevant association between the Fe status and anthropometry parameters except for the inverse correlation with the percentage of body fat (Table 2).

\subsection{The Link between the Plasma Zn, Cu, and Fe Status with Total Phospholipid FA Composition and Desaturase Enzyme Activities}

There were no significant correlations between the plasma $\mathrm{Zn}$ and any of the FAs measured in this study. Cu was directly related to oleic acid (18:1n-9) and alpha-linolenic acid (ALA, C18:3n-3). Plasma Fe correlated directly with oleic acid, while $\mathrm{Cu}: \mathrm{Zn}$ ratio was directly associated with alpha-linolenic acid (Table 3).

No statistically significant relationships were seen among the plasma status of either Zn or Fe with any of the desaturases. There was an inverse correlation trend between the LA:DGLA and $\mathrm{Zn}$ and Fe status and a direct relationship between the $\mathrm{Cu}$ and LA:DGLA ratio, without reaching statistical significance.

\subsection{The Link between the Status of the Individual FAs with Certain Components of Dyslipidemic Status (Anthropometrical and Biochemical Parameters)}

The linoleic acid correlated inversely, while arachidonic acid was directly linked to BMI (Table 4). No other significant links between the status of individual FAs and anthropometry indicators were observed. Similarly, no correlations were seen between the biochemistry related parameters and FAs, except for the direct correlations of oleic acid (C18:1 n-9) with total cholesterol and HDL-C (Table 4), and for the direct relationship between dihomo-gamma-linolenic acid (DGLA; C20:3 n6) and TGs. 
Table 2. Correlations between plasma levels of trace elements $(\mathrm{Zn}, \mathrm{Fe}, \mathrm{Cu})$ and $\mathrm{Cu}: \mathrm{Zn}$ ratio with anthropometrical and biochemical parameters in study subjects.

\begin{tabular}{|c|c|c|c|c|c|c|c|c|c|c|}
\hline & BMI & Body Fat $\%$ & FPG & TG & $\begin{array}{c}\text { Total } \\
\text { Cholesterol }\end{array}$ & LDL-C & HDL-C & Cho/HDL & LDL/HDL & Non-HDL/HDL \\
\hline $\mathrm{Cu}$ & $\begin{array}{c}\mathrm{r}=-0.147 \\
p=0.504 \\
504504\end{array}$ & $\begin{array}{l}\mathrm{r}=0.177 \\
p=0.417\end{array}$ & $\begin{array}{c}r=-0.156 \\
p=0.477\end{array}$ & $\begin{array}{c}\mathrm{r}=-0.161 \\
p=0.463\end{array}$ & $\begin{array}{l}\mathrm{r}=0.040 \\
p=0.856\end{array}$ & $\begin{array}{c}\mathrm{r}=-0.006 \\
p=0.978\end{array}$ & $\begin{array}{l}r=0.346 \\
p=0.106\end{array}$ & $\begin{array}{c}r=-0.335 \\
p=0.118\end{array}$ & $\begin{array}{c}r=-0.269 \\
p=0.215\end{array}$ & $\begin{array}{c}\mathrm{r}=-0.335 \\
p=0.118\end{array}$ \\
\hline $\mathrm{Fe}$ & $\begin{array}{c}r=-0.161 \\
p=0.463\end{array}$ & $\begin{array}{c}r=-0.497 \\
p=0.016\end{array}$ & $\begin{array}{c}\mathrm{r}=-0.097 \\
p=0.660\end{array}$ & $\begin{array}{l}r=0.128 \\
p=0.562\end{array}$ & $\begin{array}{c}r=-0.198 \\
p=0.364\end{array}$ & $\begin{array}{c}r=-0.116 \\
p=0.943\end{array}$ & $\begin{array}{c}\mathrm{r}=-0.272 \\
p=0.210\end{array}$ & $\begin{array}{l}\mathrm{r}=0.195 \\
p=0.373\end{array}$ & $\begin{array}{l}\mathrm{r}=0.212 \\
p=0.331\end{array}$ & $\begin{array}{l}\mathrm{r}=0.195 \\
p=0.373\end{array}$ \\
\hline $\mathrm{Zn}$ & $\begin{array}{l}\mathrm{r}=0.536 \\
p=0.021\end{array}$ & $\begin{array}{l}\mathrm{r}=0.161 \\
p=0.798\end{array}$ & $\begin{array}{l}\mathrm{r}=0.386 \\
p=0.069\end{array}$ & $\begin{array}{l}r=0.269 \\
p=0.215\end{array}$ & $\begin{array}{l}\mathrm{r}=0.192 \\
p=0.379\end{array}$ & $\begin{array}{l}\mathrm{r}=0.289 \\
p=0.181\end{array}$ & $\begin{array}{c}\mathrm{r}=-0.307 \\
p=0.155\end{array}$ & $\begin{array}{l}\mathrm{r}=0.469 \\
p=0.024\end{array}$ & $\begin{array}{l}\mathrm{r}=0.499 \\
p=0.015\end{array}$ & $\begin{array}{l}\mathrm{r}=0.469 \\
p=0.024\end{array}$ \\
\hline $\mathrm{Cu}: \mathrm{Zn}$ & $\begin{array}{c}\mathrm{r}=-0.488 \\
p=0.018\end{array}$ & $\begin{array}{c}\mathrm{r}=-0.065 \\
p=0.769\end{array}$ & $\begin{array}{c}\mathrm{r}=-0.349 \\
p=0.102\end{array}$ & $\begin{array}{c}\mathrm{r}=-0.298 \\
p=0.167\end{array}$ & $\begin{array}{c}\mathrm{r}=-0.109 \\
p=0.622\end{array}$ & $\begin{array}{c}\mathrm{r}=-0.203 \\
p=0.354\end{array}$ & $\begin{array}{l}\mathrm{r}=0.430 \\
p=0.041\end{array}$ & $\begin{array}{c}\mathrm{r}=-0.541 \\
p=0.008\end{array}$ & $\begin{array}{c}\mathrm{r}=-0.518 \\
p=0.011\end{array}$ & $\begin{array}{c}\mathrm{r}=-0.542 \\
p=0.008\end{array}$ \\
\hline
\end{tabular}

Abbreviations: Body Fat\%-body fat percentage; FPG-fasting plasma glucose; TG-triglycerides; Cho/HDL-total cholesterol/HDL-C ratio.

Table 3. Correlations of plasma concentrations of trace elements $(\mathrm{Zn}, \mathrm{Fe}, \mathrm{Cu})$ and $\mathrm{Cu}: \mathrm{Zn}$ ratio with plasma fatty acids and estimated desaturase activity in study subjects.

\begin{tabular}{|c|c|c|c|c|c|c|c|c|c|c|c|c|}
\hline & $18: 1 n-9$ & $18: 2 n-6$ & $18: 3 n-3$ & $20: 3 n-6$ & $20: 4 n-6$ & $20: 5 n-3$ & $22: 4 n-6$ & $22: 5 n-3$ & $22: 6 n-3$ & LA: DGLA & $\Delta 5$-Desaturase & $\Delta 6$-Desaturase \\
\hline $\mathrm{Cu}$ & $\begin{array}{l}r=0.433 \\
p=0.039\end{array}$ & $\begin{array}{l}\mathrm{r}=0.265 \\
p=0.222\end{array}$ & $\begin{array}{l}\mathrm{r}=0.542 \\
p<0.001\end{array}$ & $\begin{array}{c}\mathrm{r}=-0.194 \\
p=0.060\end{array}$ & $\begin{array}{c}\mathrm{r}=-0.267 \\
p=0.217\end{array}$ & $\begin{array}{l}\mathrm{r}=0.231 \\
p=0.290\end{array}$ & $\begin{array}{c}\mathrm{r}=-0.357 \\
p=0.095\end{array}$ & $\begin{array}{c}\mathrm{r}=-0.108 \\
p=0.624\end{array}$ & $\begin{array}{l}\mathrm{r}=0.162 \\
p=0.461\end{array}$ & $\begin{array}{l}r=0.293 \\
p=0.175\end{array}$ & $\begin{array}{c}\mathrm{r}=-0.010 \\
p=0.963\end{array}$ & $\begin{array}{c}\mathrm{r}=-0.196 \\
p=0.370\end{array}$ \\
\hline $\mathrm{Fe}$ & $\begin{array}{l}\mathrm{r}=0.415 \\
p=0.049\end{array}$ & $\begin{array}{l}\mathrm{r}=0.059 \\
p=0.788\end{array}$ & $\begin{array}{c}r=-0.503 \\
p=0.014\end{array}$ & $\begin{array}{l}r=0.157 \\
p=0.474\end{array}$ & $\begin{array}{c}\mathrm{r}=-0.092 \\
p=0.677\end{array}$ & $\begin{array}{c}\mathrm{r}=-0.021 \\
p=0.925\end{array}$ & $\begin{array}{l}\mathrm{r}=0.113 \\
p=0.609\end{array}$ & $\begin{array}{l}\mathrm{r}=0.045 \\
p=0.837\end{array}$ & $\begin{array}{c}\mathrm{r}=-0.049 \\
p=0.823\end{array}$ & $\begin{array}{c}\mathrm{r}=-0.092 \\
p=0.677\end{array}$ & $\begin{array}{c}\mathrm{r}=-0.145 \\
p=0.508\end{array}$ & $\begin{array}{l}\mathrm{r}=0.137 \\
p=0.532\end{array}$ \\
\hline $\mathrm{Zn}$ & $\begin{array}{l}\mathrm{r}=0.118 \\
p=0.330\end{array}$ & $\begin{array}{c}\mathrm{r}=-0.182 \\
p=0.380\end{array}$ & $\begin{array}{c}\mathrm{r}=-0.152 \\
p=0.696\end{array}$ & $\begin{array}{l}\mathrm{r}=0.007 \\
p=0.975\end{array}$ & $\begin{array}{l}\mathrm{r}=0.118 \\
p=0.391\end{array}$ & $\begin{array}{l}\mathrm{r}=0.131 \\
p=0.553\end{array}$ & $\begin{array}{l}\mathrm{r}=0.108 \\
p=0.622\end{array}$ & $\begin{array}{l}\mathrm{r}=0.077 \\
p=0.728\end{array}$ & $\begin{array}{l}\mathrm{r}=0.214 \\
p=0.327\end{array}$ & $\begin{array}{c}\mathrm{r}=-0.132 \\
p=0.058\end{array}$ & $\begin{array}{l}\mathrm{r}=0.168 \\
p=0.471\end{array}$ & $\begin{array}{l}\mathrm{r}=0.168 \\
p=0.443\end{array}$ \\
\hline Cu:Zn & $\begin{array}{c}r=-0.130 \\
p=0.517\end{array}$ & $\begin{array}{l}\mathrm{r}=0.297 \\
p=0.168\end{array}$ & $\begin{array}{l}\mathrm{r}=0.449 \\
p=0.026\end{array}$ & $\begin{array}{c}r=-0.118 \\
p=0.593\end{array}$ & $\begin{array}{c}\mathrm{r}=-0.305 \\
p=0.157\end{array}$ & $\begin{array}{l}\mathrm{r}=0.051 \\
p=0.816\end{array}$ & $\begin{array}{c}r=-0.345 \\
p=0.107\end{array}$ & $\begin{array}{c}r=-0.111 \\
p=0.615\end{array}$ & $\begin{array}{c}\mathrm{r}=-0.036 \\
p=0.872\end{array}$ & $\begin{array}{c}\mathrm{r}=-0.243 \\
p=0.244\end{array}$ & $\begin{array}{c}\mathrm{r}=-0.120 \\
p=0.586\end{array}$ & $\begin{array}{c}r=-0.243 \\
p=0.264\end{array}$ \\
\hline
\end{tabular}


Table 4. Correlations between individual plasma fatty acids with anthropometrical and biochemical parameters in study subjects.

\begin{tabular}{|c|c|c|c|c|c|c|}
\hline & BMI & Body Fat $\%$ & TG & Cholesterol & LDL-C & HDL-C \\
\hline $18: 1 n-9$ & $\begin{array}{c}\mathrm{r}=-0.065 \\
p=0.746\end{array}$ & $\begin{array}{l}\mathrm{r}=0.193 \\
p=0.334\end{array}$ & $\begin{array}{c}\mathrm{r}=-0.330 \\
p=0.093\end{array}$ & $\begin{array}{l}\mathrm{r}=0.474 \\
p=0.012\end{array}$ & $\begin{array}{l}\mathrm{r}=0.266 \\
p=0.180\end{array}$ & $\begin{array}{l}\mathrm{r}=0.660 \\
p<0.001\end{array}$ \\
\hline $18: 2 n-6$ & $\begin{array}{c}\mathrm{r}=-0.458 \\
p=0.016\end{array}$ & $\begin{array}{c}\mathrm{r}=-0.317 \\
p=0.107\end{array}$ & $\begin{array}{c}\mathrm{r}=-0.028 \\
p=0.888\end{array}$ & $\begin{array}{c}\mathrm{r}=-0.362 \\
p=0.063\end{array}$ & $\begin{array}{c}\mathrm{r}=-0.310 \\
p=0.116\end{array}$ & $\begin{array}{c}\mathrm{r}=-0.107 \\
p=0.597\end{array}$ \\
\hline $18: 3 n-3$ & $\begin{array}{c}\mathrm{r}=-0.057 \\
p=0.777\end{array}$ & $\begin{array}{l}\mathrm{r}=0.301 \\
p=0.127\end{array}$ & $\begin{array}{c}r=-0.127 \\
p=0.527\end{array}$ & $\begin{array}{l}r=0.005 \\
p=0.979\end{array}$ & $\begin{array}{c}\mathrm{r}=-0.181 \\
p=0.367\end{array}$ & $\begin{array}{l}r=0.233 \\
p=0.243\end{array}$ \\
\hline $20: 3 n-6$ & $\begin{array}{l}\mathrm{r}=0.270 \\
p=0.173\end{array}$ & $\begin{array}{l}\mathrm{r}=0.168 \\
p=0.403\end{array}$ & $\begin{array}{l}\mathrm{r}=0.560 \\
p=0.002\end{array}$ & $\begin{array}{l}\mathrm{r}=0.185 \\
p=0.355\end{array}$ & $\begin{array}{l}\mathrm{r}=0.243 \\
p=0.222\end{array}$ & $\begin{array}{c}\mathrm{r}=-0.339 \\
p=0.083\end{array}$ \\
\hline $20: 4 n-6$ & $\begin{array}{l}r=0.416 \\
p=0.031\end{array}$ & $\begin{array}{l}\mathrm{r}=0.245 \\
p=0.217\end{array}$ & $\begin{array}{c}\mathrm{r}=-0.135 \\
p=0.502\end{array}$ & $\begin{array}{l}\mathrm{r}=0.118 \\
p=0.557\end{array}$ & $\begin{array}{l}r=0.089 \\
p=0.658\end{array}$ & $\begin{array}{l}\mathrm{r}=0.109 \\
p=0.614\end{array}$ \\
\hline $20: 5 n-3$ & $\begin{array}{c}\mathrm{r}=0.223 \\
p>0.05\end{array}$ & $\begin{array}{c}r=0.261 \\
p>0.05\end{array}$ & $\begin{array}{c}\mathrm{r}=-0.106 \\
p>0.05\end{array}$ & $\begin{array}{c}r=0.029 \\
p>0.05\end{array}$ & $\begin{array}{c}\mathrm{r}=-0.016 \\
p>0.05\end{array}$ & $\begin{array}{c}r=0.134 \\
p>0.05\end{array}$ \\
\hline $22: 4 n-6$ & $\begin{array}{c}\mathrm{r}=-0.080 \\
p=0.970\end{array}$ & $\begin{array}{c}\mathrm{r}=-0.204 \\
p=0.306\end{array}$ & $\begin{array}{l}\mathrm{r}=0.102 \\
p=0.612\end{array}$ & $\begin{array}{c}\mathrm{r}=-0.036 \\
p=0.860\end{array}$ & $\begin{array}{c}\mathrm{r}=-0.168 \\
p=0.967\end{array}$ & $\begin{array}{c}\mathrm{r}=-0.162 \\
p=0.421\end{array}$ \\
\hline $22: 5 n-3$ & $\begin{array}{l}\mathrm{r}=0.009 \\
p=0.965\end{array}$ & $\begin{array}{l}\mathrm{r}=0.011 \\
p=0.957\end{array}$ & $\begin{array}{c}\mathrm{r}=-0.107 \\
p=0.597\end{array}$ & $\begin{array}{l}\mathrm{r}=0.011 \\
p=0.955\end{array}$ & $\begin{array}{c}\mathrm{r}=-0.028 \\
p=0.692\end{array}$ & $\begin{array}{l}\mathrm{r}=0.080 \\
p=0.889\end{array}$ \\
\hline $22: 6 n-3$ & $\begin{array}{l}\mathrm{r}=0.294 \\
p=0.136\end{array}$ & $\begin{array}{l}\mathrm{r}=0.201 \\
p=0.314\end{array}$ & $\begin{array}{l}r=0.024 \\
p=0.905\end{array}$ & $\begin{array}{l}\mathrm{r}=0.029 \\
p=0.885\end{array}$ & $\begin{array}{l}\mathrm{r}=0.153 \\
p=0.447\end{array}$ & $\begin{array}{c}\mathrm{r}=-0.143 \\
p=0.477\end{array}$ \\
\hline
\end{tabular}

Abbreviations: Body Fat\%-body fat percentage; TG-triglycerides.

3.5. Correlations between LA:DGLA Ratio and Estimated Desaturase Activities with FAs, Anthropometrical, and Biochemical Indices

The LA:DGLA ratio was inversely linked to BMI (Table 5). Predicted activities of $\Delta 5$ and $\Delta 9$ desaturases were not linked to any anthropometry measure, while $\Delta 6$ desaturases was directly related to BMI. LA:DGLA was inversely associated with TG, Cho/HDL ratio and non-HDL/HDL. $\Delta 5$ desaturase was inversely related to TG levels (Table 5). $\Delta 6$ and $\Delta 9$ desaturases have not been linked to any of the biochemistry related parameters assessed. $\Delta 5$ desaturase was directly related with arachidonic and docosahexaenoic and inversely with LA and DGLA (Table 5).

The linoleic acid was directly associated with the LA:DGLA ratio and inversely linked to all desaturases. The relations among FAs and projected desaturase activities were not affected by plasma Zn concentrations upon addition to the partial correlation models (data not presented).

Table 5. Correlations between LA:DGLA ratio and desaturase activities with the status of individual plasma fatty acids, BMI, and biochemical parameters in study subjects.

\begin{tabular}{cccccccccc}
\hline & $\mathbf{1 8 : 2} \boldsymbol{n - 6}$ & $\mathbf{2 0 : 3} \boldsymbol{n - 6}$ & $\mathbf{2 0 : 4} \boldsymbol{n - 6}$ & $\mathbf{2 2 : 6} \boldsymbol{n - 3}$ & BMI & TG & Cho/HDL & LDL/HDL & Non-HDL/HDL \\
\hline \multirow{2}{*}{ LA:DGLA Ratio } & $\mathrm{r}=0.470$ & $\mathrm{r}=-0.889$ & $\mathrm{r}=-0.209$ & $\mathrm{r}=-0.008$ & $\mathrm{r}=-0.418$ & $\mathrm{r}=-0.506$ & $\mathrm{r}=-0.433$ & $\mathrm{r}=-0.362$ & $\mathrm{r}=-0.433$ \\
& $p=0.013$ & $p<0.001$ & $p=0.296$ & $p=0.969$ & $p=0.030$ & $p=0.007$ & $p=0.024$ & $p=0.063$ & $p=0.024$ \\
\hline \multirow{2}{*}{$\Delta$ 5-Desaturase } & $\mathrm{r}=-0.406$ & $\mathrm{r}=-0.710$ & $\mathrm{r}=0.694$ & $\mathrm{r}=0.441$ & $\mathrm{r}=0.085$ & $\mathrm{r}=-0.392$ & $\mathrm{r}=-0.301$ & $\mathrm{r}=-0.240$ & $\mathrm{r}=-0.301$ \\
& $p=0.035$ & $p<0.001$ & $p<0.001$ & $p=0.021$ & $p=0.672$ & $p=0.043$ & $p=0.243$ & $p=0.454$ & $p=240$ \\
\hline \multirow{2}{*}{$\Delta$ 6-Desaturase } & $\mathrm{r}=-0.627$ & $\mathrm{r}=0.200$ & $\mathrm{r}=0.311$ & $\mathrm{r}=-0.075$ & $\mathrm{r}=0.398$ & $\mathrm{r}=0.194$ & $\mathrm{r}=0.125$ & $\mathrm{r}=0.132$ & $\mathrm{r}=0.127$ \\
& $p<0.001$ & $p=0.317$ & $p=0.114$ & $p=0.710$ & $p=0.040$ & $p=0.334$ & $p=0.533$ & $p=0.510$ & $p=0.527$ \\
\hline \multirow{2}{*}{$\Delta$ 9-Desaturase } & $\mathrm{r}=-0.402$ & $\mathrm{r}=0.212$ & $\mathrm{r}=0.056$ & $\mathrm{r}=-0.086$ & $\mathrm{r}=0.284$ & $\mathrm{r}=0.239$ & $\mathrm{r}=0.112$ & $\mathrm{r}=0.091$ & $\mathrm{r}=0.111$ \\
& $p=0.037$ & $p=0.289$ & $p=0.781$ & $p=0.669$ & $p=0.152$ & $p=0.230$ & $p=0.578$ & $p=0.653$ & $p=0.581$ \\
\hline
\end{tabular}

Abbreviations: TG-triglycerides; Cho/HDL-total cholesterol/HDL-C ratio.

\subsection{Dietary Zn Intake of Participants}

The average daily dietary $\mathrm{Zn}$ intake was $7.42 \pm 1.82 \mathrm{mg} /$ day with about $65 \%$ of study participants having intakes below the recommendations (8-11 mg/day) [55]. Grains and grain products (white 
and wholemeal bread) were the most significant sources of dietary $\mathrm{Zn}$, contributing $21.5 \%$ to the total intake. Other important sources were meat and meat products (chicken meat) and milk and dairy products (yoghurt), with an estimated contribution of $20 \%$ and $15 \%$ to Zn intake, respectively (Table 6). Top ten food sources of $\mathrm{Zn}$ in participants' diets are presented in Figure 1.

Table 6. Contribution of different food groups to dietary Zn intake of study participants.

\begin{tabular}{lcc}
\hline Food Group & Average Zn Intake, Mg & Contribution to Zn Intake, \% \\
\hline Grains and Grain Products & 1.595 & 21.49 \\
Meat and Meat Products & 1.499 & 20.20 \\
Milk and Dairy Products & 1.104 & 14.88 \\
Vegetables and Vegetable Products & 0.888 & 11.97 \\
Nuts, Seeds, and Kernels & 0.789 & 10.63 \\
Eggs and Egg Products & 0.514 & 6.93 \\
Fruit and Fruit Products & 0.336 & 4.53 \\
Non-Milk Beverages & 0.314 & 4.23 \\
Sugar and Sweets & 0.141 & 1.90 \\
Seafood and Related Products & 0.152 & 2.05 \\
Miscellaneous Food Products & 0.081 & 1.09 \\
Fat and Oil & 0.008 & 0.11 \\
\hline
\end{tabular}
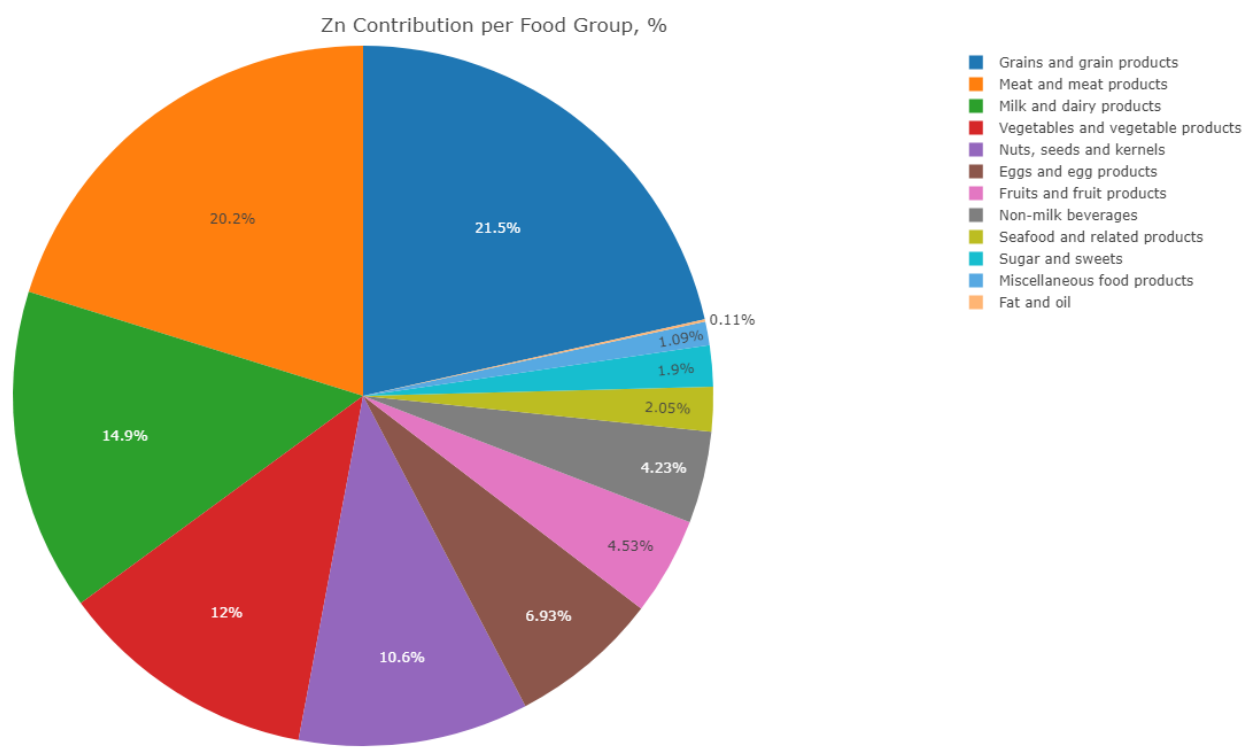

Figure 1. Top ten food sources of $\mathrm{Zn}$ in participants' diets.

There was no correlation between the dietary Zn intake and plasma Zn status $(p>0.05)$. The dietary $\mathrm{Zn}$ intake was inversely correlated with the LA:DGLA ratio ( $\mathrm{r}=-0.38, p=0.05)$, while there was no significant relationship seen between the LA:DGLA ratio and dietary intake of $\mathrm{Cu}(\mathrm{r}=-0.22, p=0.26)$. Dietary $\mathrm{Zn}$ intake did not correlate with any of the biochemical or anthropometrical parameters measured within this study (data not presented). No associations were found between the dietary $\mathrm{Zn}$ intake and plasma status of individual FAs, except for the DGLA which was directly linked to the dietary $\mathrm{Zn}$ intake ( $\mathrm{r}=0.47, p=0.03)$.

The average daily dietary intakes of $\mathrm{Fe}$ and $\mathrm{Cu}$ were $9.6 \mathrm{mg}$ and $1.4 \mathrm{mg}$ per day, respectively. Dietary intake of $\mathrm{Cu}$ was inversely linked to delta 5 desaturase (AA:DGLA), $\mathrm{r}=-0.395, p=0.04$. Dietary intake of individual fatty acids has mainly not been correlated with their status. The exceptions were 20:3 n6 and 20:5n-3. The link between the eicosapentaenoic acid (EPA; C20:5n-3) status and intake was $r=0.384, p=0.048$. Intake of DGLA (20:3 n6) has been linked to the status of EPA, DPA, DHA inversely $(\mathrm{r}=-0.41, \mathrm{r}=-0.21, \mathrm{r}=0.47 ; p<0.05$, respectively) and with adrenic acid (C22:4 n6) directly $(r=0.439, p=0.03)$. 


\section{Discussion}

This study reports on the trace elements levels in plasma ( $\mathrm{Zn}, \mathrm{Cu}$ and $\mathrm{Fe}$ ), anthropometrical, biochemical and fatty acid status in a sample of dyslipidemic adult subjects residing in Serbia. It examines the link between dietary $\mathrm{Zn}$ intake and concentrations of minerals with lipid profile indicators, fatty acid composition, and desaturase enzyme activities. People with dyslipidemia have inadequate dietary intakes of Zn, low plasma Zn status, and an altered FA composition. The concentrations of plasma Zn were linked to BMI and obesity, and there was no correlation between the dietary $\mathrm{Zn}$ intake and plasma $\mathrm{Zn}$ status. The ability of the LA:DGLA ratio to respond to variations in dietary $\mathrm{Zn}$ intake is reconfirmed. $\mathrm{Cu}$, along with $\mathrm{Zn}$, may have a role in activity of desaturase enzymes. Mean plasma $\mathrm{Zn}$ concentration was $0.75 \mathrm{mg} / \mathrm{L}$. The percentage of people with low plasma $\mathrm{Zn}$ concentrations using the IZiNGs criteria was 30\% (50\% with levels below $0.75 \mathrm{mg} / \mathrm{L})$, which indicates the presence of $\mathrm{Zn}$ deficiency in this study population [53]. There were no subjects with plasma $\mathrm{Zn}$ levels under $0.5 \mathrm{mg} / \mathrm{L}$, most likely due to a proficient homeostatic regulation of Zn. Our findings are in line with Obeid et al. [56] who also demonstrated a risk of Zn deficiency in Lebanese subjects with metabolic syndrome. The low plasma $\mathrm{Zn}$ concentrations were also seen in obese individuals, those with hypertension and type 2 diabetes [57,58]. Fe and $\mathrm{Cu}$ status data were within the estimated reference ranges for adult population, and similar to the values reported elsewhere [33,59]. The highest concentrations of $\mathrm{Cu}$ were seen in people with the lowest levels of plasma $\mathrm{Zn}$. At the same time, the lowest concentrations of plasma Fe were found in a group of people with the lowest plasma $\mathrm{Zn}$ status. Decrease in serum Zn levels with a parallel increase in serum $\mathrm{Cu}$ concentrations has previously been reported in patients with myocardial infraction [60] and metabolic syndrome [61]. Similarly, concomitant decreases in the concentrations of both Fe and $\mathrm{Zn}$ have been described in the past $[62,63]$. No intercorrelations were seen between the concentrations of trace elements, which was also in accordance with some previously reported data $[64,65]$. Serum Cu:Zn is a useful indicator for identification of various diseases [66,67], including Zn deficiency [68]. Imbalances in the metabolism of $\mathrm{Zn}$ and $\mathrm{Cu}$ predispose to dyslipidemia, increased arteriosclerosis and cardiovascular diseases [69,70]. The ratio of $\mathrm{Cu}: \mathrm{Zn}$ is believed to be clinically more relevant than the individual concentrations of either of these trace elements, and it is often used to show the general health state of an individual as it is very easily affected by inflammatory conditions [71]. The optimal plasma Cu:Zn ratio is in the range 0.7-1.00 [72] and the levels of 1.3 measured in this study certainly reflect a decreased nutritional $\mathrm{Zn}$ status, but also an inflammatory response. The reduction in plasma Zn levels in this study group could be explained by an increased uptake of $\mathrm{Zn}$ by tissues. Additionally, due to the presence of slight inflammation there may be change in the protein Zn-binding capacities [73]. Furthermore, the plasma Zn status did not correlate with dietary Zn intake, which is expected [33,74]. Sixty-five percent of our study sample did not meet dietary $\mathrm{Zn}$ requirements, which certainly contributed to low plasma $\mathrm{Zn}$ concentrations. Low dietary intake of $\mathrm{Zn}$ is found in people with a higher prevalence of coronary risk factors [70]. The bioavailability of $\mathrm{Zn}$ from the diet is highly dependent on the phytate: Zn molar ratio, and ratios above 15 are associated with a marked reduction in $\mathrm{Zn}$ absorption [53,75]. Dietary data are showing that major sources of $\mathrm{Zn}$ in our study group are plant sources (cereals-white and wholemeal bread), legumes and vegetables) with acknowledged high phytate content [76].

As majority of other databases, our database did not contain data on the amount of phytates in selected foods, so the exact phytate: Zn molar ratio of consumed foods was not obtained. However, when method by Jati et al. [77] was employed, Zn bioavailability from the diets consumed by our participants fitted into the group of 'high bioavailability' where $\leq 50 \%$ of total energy intake is accounted for from rice, other grains, other starchy staples, and pulses and nuts (35\% in this group) and $>5 \%$ (7.5\% in our study sample) of total energy intake is accounted for by protein from fish, eggs, dairy, and meat. The association between anthropometric indicators and status of certain trace elements in a dyslipidemic population has been investigated in the past [78,79]. As with earlier findings [80,81] in our study no relationships were found between the statuses of trace elements with age. The increasing concentration of plasma Zn was associated with higher BMI and weight, 
similar to previous reports [33,82,83]. Yu et al. [61] reported comparable results in metabolic syndrome patients, higher serum Zn levels in those with higher weight. However, an inverse relation has also been reported $[79,84]$, and future studies in large dyslipidemic cohorts are needed to derive decisive conclusions. Majority of our participants were either Zn deficient or with borderline Zn deficiency, which might be in line with potential mechanistic background of the observed correlations. $\mathrm{Zn}$ is an antioxidant, involved in the production of metalloenzymes and plays an important role in the metabolism of fats [85]. Zn dependent alpha2-glycoprotein (ZAG) is an adipokine which stimulates energy expenditure in skeletal muscle and brown adipose tissues resulting in reductions in body weight and TGs [86]. Additional studies with more diverse dietary and/or plasma Zn statuses of participants are needed to explore the causality of the associations observed herein. Similar to our study, previous reports failed to demonstrate the relationship between serum $\mathrm{Cu}$ and Fe concentrations with cholesterol and TG levels [17,82]. On the contrary, plasma $\mathrm{Zn}$ was directly and $\mathrm{Cu}: \mathrm{Zn}$ ratio inversely associated with LDL/HDL, Cho/HDL and non-HDL/HDL. Inconsistent data are reported in the literature, a direct correlation between $\mathrm{Zn}$ and HDL [87,88] but also an inverse relationship [79,82]. An imbalance in the metabolism of $\mathrm{Cu}$ has been linked to hypercholesterolemia and an increased $\mathrm{Cu}: \mathrm{Zn}$ superoxide dismutase was detected in obese individuals [89]. This obvious opposition between $\mathrm{Zn}$ and $\mathrm{Cu}$ has been acknowledged in hypertension [90], type 2 diabetes [91] and elevated blood pressure [92]. Zn can have an endogenous protective role against dyslipidemia and arteriosclerosis as it can inhibit the oxidation of LDL-C and protect against inflammatory diseases by inhibiting the activation of oxidative stress $[82,93]$. In our study, the insufficient dietary Zn intake and low plasma Zn concentrations could alter the lipid status and contribute to development of dyslipidemia. The wider ranging studies are now required to determine the exact order and underlying mechanisms of observed interactions further. Little is known about the relation between the desaturase enzyme activities and common dyslipidemic parameters. Increased $\Delta 6$ and $\Delta 9$ and reduced $\Delta 5$ desaturase activities are seen in people with chronic diseases [28,61,94]. In accordance with the data from other studies [29,95,96] herein the $\Delta 6$ and $\Delta 9$ desaturase activities were directly linked to BMI. Finally, the LA:DGLA ratio was inversely associated with BMI, Cho/HDL ratio and non-HDL/HDL and TG. The observed relations between the desaturases and biochemistry related parameters may result from the alterations in the desaturases encoding genes (FADS 1 and FADS2) that are linked to serum HDL-C and TG [97,98]. Moreover, desaturase enzymes are coupled to the NAD (P) H-cytochrome b5 electron transferrin chain and insufficient dietary Zn intake might affect the electron transferring chain and subsequently change the activities of desaturases and their relationship with lipid status parameters [99]. Furthermore, Zn modifies cyclooxy-genase activity and it acts as a co-enzyme for $\Delta 6$ desaturase [31-33,39]. The link between the $\Delta 6$ desaturase and $\mathrm{Zn}$ has been studied both in animals and humans [32,34,35,39]. The LA:DGLA ratio has been proposed as a potentially new biomarker of $\mathrm{Zn}$ status as it has been demonstrated that the ratio changes in accordance to dietary $\mathrm{Zn}$ manipulations [32,33,39]. However, the sensitivity of this biomarker to predict $\mathrm{Zn}$ status in $\mathrm{Zn}$ deficient human populations, as well as in people with an apparent presence of inflammatory conditions has not been explored so far. In this study, an inverse relationship among the LA:DGLA ratio and nutritional $\mathrm{Zn}$ status has been confirmed. Similarly, a noteworthy association was observed between the LA:DGLA ratio and plasma levels of $\mathrm{Cu}$. $\mathrm{Cu}$ is the third most abundant essential trace element in the human body, and similarly to $\mathrm{Zn}$, it also acts as a part of antioxidant enzymes that protects against free radicals [100]. Zn and $\mathrm{Cu}$ are known as interacting metallic elements, and an antagonistic relationship between $\mathrm{Zn}$ and $\mathrm{Cu}$ has been previously presented [89,101]. Herein, the lower than recommended dietary intake of $\mathrm{Zn}$ possibly contributed development of $\mathrm{Zn}$ deficiency and lead to a slightly misbalanced $\mathrm{Cu}: \mathrm{Zn}$ ratio. The previously noted inverse trend between the LA:DGLA ratio and dietary $\mathrm{Zn}$ intakes has been reconfirmed in this study, and the detected borderline statistical significance was most likely due to the relatively uniform dietary Zn intakes of participants. Demonstrated altered $\mathrm{Cu}: \mathrm{Zn}$ ratio demonstrates that the balance of these minerals is disturbed to a certain degree, in which situation $\mathrm{Cu}$ may be taking over Zn's role, which is shown by a significant relationship seen between the plasma $\mathrm{Cu}$ concentrations and the LA:DGLA ratio. $\mathrm{Cu}$ may have a 
unique effect on long-chain FA metabolism [30]. In the early 1971, Brenner \& Catala proposed that Cu can act on a metabolic pathway common to all FA desaturases, as a component of cupoprotein enzymes. As with findings of this study, a positive correlation has been described, an increase in desaturase activity with addition of $\mathrm{Cu}[102,103]$. Active conversion of linoleic acid (LA) to its metabolites (GLA and DGLA) depends on the levels of these trace elements, higher levels of $\mathrm{Zn}$ and lower levels of $\mathrm{Cu}$ are an expected basis for an increased desaturase activity. It seems that $\mathrm{Zn}$ and $\mathrm{Cu}$ misbalance may be an active modifier of the LA:DGLA activity in dyslipidemia; however, this should be confirmed by further studies. The FA composition of serum phospholipids of this study group was similar to FA statuses of patients reported in other studies, but the values for $n-3$ PUFAs were lower from the values reported for healthy people [104-106]. The low intake and status of $n-3$ PUFA has been shown in obese populations and those with metabolic syndrome [61]. Low levels of $n$-3 PUFA are known to decrease the expression of mitochondrial messenger ribonucleic acid (RNA), which plays a role in a defense against obesity [107]. The overconsumption of $n-6$ PUFA and a high ratio of $n-6$ to $n-3$ PUFA may add to the increased obesity and dyslipidemia by stimulating low-grade chronic inflammation. N-3 PUFA influences obesity through eicosanoid modulation leading to a decrease in inflammation [106,108]. As expected there was the highest concentration of omega-6 FAs that are known as 'pro-inflammatory' and the lowest amount of omega-3 FA 'anti-inflammatory' in participants' diets. The idea of n-6 FAs as 'harmful' is starting to change [109]. New evidence is showing that high levels of LA are inversely linked to the risk of development of cardiovascular diseases and mortality. The highest blood levels of LA in addition to $n$-3 FA reduced a risk of death for more than 50\% [109]. However, the intake of $n-3$ FAs of participants in this group was below recommended intakes. In addition, the concentration of adrenic acid (22:4 n-6) increased in this study group, when compared to other reports in the literature [59,110]. 22:4 n-6 has a direct influence on the IKKb/NF-kB and inflammation signaling [111] which can promote type 2 diabetes and obesity [112], so adequate concentrations of this acid may be of great importance for prevention of obesity and dyslipidemia. Similarly, the $n 6 / n 3$ PUFA ratio in Western diets (projected to be 10-25:1) has increased together with the prevalence of obesity and cardiovascular disease [113]. The reduction from 5:1 to 2:1 had a beneficial effect in preventing and treating a chronic disease [114]. In this study group, the ratio of 12:1 was higher than recommended, therefore achieving a much lower ratio may be beneficial for this dyslipidemic cohort. Very limited information is available on the role of $\mathrm{Cu}, \mathrm{Zn}$ and Fe in FA metabolism in a dyslipidemic population. There were no statistically significant correlations between the plasma $\mathrm{Zn}$ and Fe with the statuses of any of the FAs measured within this study. Cu: $\mathrm{Zn}$ ratio was not linked to the status of individual FAs, while the plasma $\mathrm{Cu}$ was directly related to (alpha-linolenic acid (ALA,C18:3n-3). Finally, it would be beneficial to explore whether the examined associations remain after the improved dietary intake of $n-3$ FAs and to what extend are potential dietary modifications able to diminish development of dyslipidemia and related disorders. Palmitoleic acid (C16:1 n-7), a monounsaturated FA correlated directly with BMI while oleic acid (C18:1 n-9) was linked to total cholesterol, which, if serum FA is used as a surrogate indicator of the dietary intake of FA, means that there is an increased dietary intake of monounsaturated FAs which contribute to increased cholesterol levels and obesity. This was supported by the dietary intake data, saturated fats contributed 13\% to the total energy intake, while only $30 \%$ of fats consumed by this group was coming from PUFA sources. The direct correlation was also observed between the dietary intakes of fats with weight related indicators, which is in accordance with some previous reports $[115,116]$. Diets high in saturated fats and low in PUFAs may lead to the development of dyslipidemia. To sum up, Zn deficiency (and altered Cu:Zn ratio) could be important factors in decreased desaturase activity and modified FA metabolism. The obtained results should be interpreted with caution as reverse interconnections cannot be totally excluded. Although conducted within limited sample-size, our study results provide a valuable basis for further evaluation of the role of important trace elements ( $\mathrm{Fe}, \mathrm{Cu}$ and $\mathrm{Zn}$ ) in the development of dyslipidemia and related conditions. The strengths of this study are the use of an entire range of independent biomarkers of dyslipidemic status: serum FAs, plasma mineral concentrations, anthropometrical, biochemical, and dietary intake 
data. Blood levels of several individual FAs are investigated rather than FA groups. Limitations of the present study include a lack of a directly measured inflammation indicators that could be assessed as potential confounders to relations of interest and a surrogate measure of desaturase enzyme activities. However, $\mathrm{Cu}: \mathrm{Zn}$ ratio was used as an indicator for the presence of inflammation. Direct measurements of desaturase activities are challenging for ethical reasons, so the method used to estimate desaturase activity, the precursor-to-product ratio has frequently been used and has been shown to correlate well with desaturase expression in human liver biopsies [117]. Method employed to validate bioavailability of $\mathrm{Zn}$ is also generally accepted and often used in dietary data analysis. As far as we are aware, this is the first study that documents plasma levels of $\mathrm{Zn}, \mathrm{Cu}$, and $\mathrm{Fe}$ in relation to an entire range of anthropometrical, biochemical, FA status components, and desaturases activities in people suffering from dyslipidemia. It was certainly the first study of this type in Serbia.

\section{Conclusions}

The results offered in the present study add novel information to the limited body of literature on the relationship between the important trace elements $(\mathrm{Zn}, \mathrm{Cu}$ and $\mathrm{Fe}$ ) with fat intake and FA metabolism in people with dyslipidemia. We showed that people with dyslipidemia have inadequate dietary intakes of $\mathrm{Zn}$ and a low plasma $\mathrm{Zn}$ status. The increased $\mathrm{Cu}: \mathrm{Zn}$ ratio indicates the presence of a low-grade inflammatory conditions in this group. There were no correlations between the plasma $\mathrm{Zn}$ and dietary $\mathrm{Zn}$ intake, and the increase in the concentration of plasma $\mathrm{Zn}$ was correlated with obesity. Observed alterations in serum FA composition are most likely caused by Zn deficiency and an altered $\mathrm{Cu}: \mathrm{Zn}$ ratio. The inverse correlation between the dietary $\mathrm{Zn}$ intakes and the LA:DGLA ratio has been reconfirmed. The LA:DGLA ratio was directly linked to plasma levels of $\mathrm{Cu}$, which implies that $\mathrm{Cu}$, in addition to $\mathrm{Zn}$, may have a role in activity of desaturase enzymes, particularly in Zn deficient people and in those affected by inflammatory conditions. Dietary modifications related to the microelements appear as suitable therapeutic strategies for people suffering from dyslipidemia, and further research in the field is needed.

Author Contributions: M.K. participated in the evaluation of data, wrote the paper and prepared the manuscript for submission to the journal. A.P. contributed to the design of the study and performed the statistical analysis. M.Z. (Milica Zekovic) accountable for dietary data analysis and presentation of data. Z.P. completed mineral analysis. M.G. provided essential materials and revised the final draft of the paper. M.Z. (Manja Zec) responsible for carrying out the human study, for its design and coordination, helped with data analysis and interpretation. All authors have read and agreed to the published version of the manuscript.

Funding: The work was supported by the Ministry of Education and Science of the Republic of Serbia (Grant III 41030) and EU FP7 BACCHUS project (grant agreement number 312090).

Acknowledgments: We are grateful to the study participants and personnel involved during the study.

Conflicts of Interest: The authors declare no conflict of interest.

\section{References}

1. World Health Organization. Obesity and Overweight; 2018; N³11 WFS. Available online: https://www.who. int/news-room/fact-sheets/detail/obesity-and-overweight (accessed on 4 June 2019).

2. Alberti, K.G.; Zimmet, P.; Shaw, J. The metabolic syndrome-A new worldwide definition. Lancet 2005, 366, 1059-1062. [CrossRef]

3. Bettger, W.J.; Reeves, P.G.; Moscatelli, E.A.; Reynolds, G.; O'Dell, B.L. Interaction of zinc and essential fatty acids in the rat. J. Nutr. 1979, 109, 480-488. [CrossRef] [PubMed]

4. Franssen, R.; Monajemi, H.; Stroes, E.S.; Kastelein, J.J. Obesity and dyslipidemia. Med. Clin. N. Am. 2011, 95, 893-902. [CrossRef] [PubMed]

5. Kannel, W.B.; Doyle, J.T.; Ostfeld, A.M.; Jenkins, C.D.; Kuller, L.; Podell, R.N.; Stamler, J. Optimal resources for primary prevention of atherosclerotic diseases. Atherosclerosis study group. Circulation 1984, 70, 155a-205a.

6. Hauner, H.; Stangl, K.; Schmatz, C.; Burger, K.; Blomer, H.; Pfeiffer, E.F. Body fat distribution in men with angiographically confirmed coronary artery disease. Atherosclerosis 1990, 85, 203-210. [CrossRef] 
7. Grundy, S.M.; Stone, N.J.; Bailey, A.L.; Beam, C.; Birtcher, K.K.; Blumenthal, R.S.; Braun, L.T.; de Ferranti, S.; Faiella-Tommasino, J.; Forman, D.E.; et al. 2018aha/acc/aacvpr/aapa/abc/acpm/ada/ags/apha/aspc/nla/pcna guideline on the management of blood cholesterol. J. Am. Coll. Cardiol. 2018, 25, 3168-3209.

8. Laurant, P.; Kantelip, J.P.; Berthelot, A. Dietary magnesium supplementation modifies blood pressure and cardiovascular function in mineralocorticoid-salt hypertensive rats but not in normotensive rats. J. Nutr. 1995, 125, 830-841.

9. Castillo-Duran, C.; Cassorla, F. Trace minerals in human growth and development. JPEM 1999, $12,589-601$. [CrossRef]

10. Prashanth, L.; Kattapagari, K.K.; Chitturi, R.T.; Baddam, V.R.; Prasad, L.K. A review on role of essential trace elements in health and disease. J. NTR Univ. Health Sci. 2015, 4, 75-85.

11. Prasad, A.S. Clinical, immunological, anti-inflammatory and antioxidant roles of zinc. Exp. Gerontol. 2008, 43, 370-377. [CrossRef]

12. Uauy, R.; Olivares, M.; Gonzalez, M. Essentiality of copper in humans. Am. J. Clin. Nutr. 1998, 67, 952s-959s. [CrossRef] [PubMed]

13. Turnlund, J.R. Copper, 10th ed.; Lippincott Williams \& Wilkins: Philadelphia, PA, USA, 2006; pp. $286-299$.

14. Kruse-Jarres, J.D.; Rükgauer, M. Trace elements in diabetes mellitus. Peculiarities and clinical validity of determinations in blood cells. J. Trace Elem. Med. Biol. 2000, 14, 21-27. [CrossRef]

15. Aguilar, M.; Saavedra, P.; Arrieta, F.; Mateos, C.; González-Muñoz, M.J.; Meseguer, I.; Martinez-Para, M.C. Plasma mineral content in type-2 diabetic patients and their association with the metabolic syndrome. Ann. Nutr. Metab. 2007, 51, 402-406. [CrossRef] [PubMed]

16. Garcia, O.P.; Long, K.Z.; Rosado, J.L. Impact of micronutrient deficiencies on obesity. Nutr. Rev. 2009, 67, 559-572. [CrossRef] [PubMed]

17. Hughes, S.; Samman, S. The effect of zinc supplementation in humans on plasma lipids, antioxidant status and thrombogenesis. J. Am. Coll. Nutr. 2006, 25, 285-291. [CrossRef] [PubMed]

18. Altekin, E.; Coker, C.; Sisman, A.R.; Onvural, B.; Kuralay, F.; Kirimli, O. The relationship between trace elements and cardiac markers in acute coronary syndromes. J. Trace Elem. Med. Biol. 2005, 18, 235-242. [CrossRef]

19. Reunanen, A.; Knekt, P.; Marniemi, J.; Maki, J.; Maatela, J.; Aromaa, A. Serum calcium, magnesium, copper and zinc and risk of cardiovascular death. Eur. J. Clin. Nutr. 1996, 50, 431-437.

20. Stadler, N.; Lindner, R.A.; Davies, M.J. Direct detection and quantification of transition metal ions in human atherosclerotic plaques: Evidence for the presence of elevated levels of iron and copper. Arterioscle. Thromb. Vasc. Biol. 2004, 24, 949-954. [CrossRef]

21. Ma, J.; Folsom, A.R.; Shahar, E.; Eckfeldt, J.H. Plasma fatty acid composition as an indicator of habitual dietary fat intake in middle-aged adults. The atherosclerosis risk in communities (aric) study investigators. Am. J. Clin. Nutr. 1995, 62, 564-571. [CrossRef]

22. Vessby, B.; Gustafsson, I.B.; Tengblad, S.; Boberg, M.; Andersson, A. Desaturation and elongation of fatty acids and insulin action. Ann. N. Y. Acad. Sci. 2002, 967, 183-195. [CrossRef]

23. Esposito, K.; Marfella, R.; Ciotola, M.; Di Palo, C.; Giugliano, F.; Giugliano, G.; D'Armiento, M.; D'Andrea, F.; Giugliano, D. Effect of a mediterranean-style diet on endothelial dysfunction and markers of vascular inflammation in the metabolic syndrome: A randomized trial. JAMA 2004, 292, 1440-1446. [CrossRef] [PubMed]

24. Carpentier, Y.A.; Portois, L.; Malaisse, W.J. N-3 fatty acids and the metabolic syndrome. Am. J. Clin. Nutr. 2006, 83, 1499s-1504s. [CrossRef] [PubMed]

25. Warensjo, E.; Riserus, U.; Vessby, B. Fatty acid composition of serum lipids predicts the development of the metabolic syndrome in men. Diabetologia 2005, 48, 1999-2005. [CrossRef] [PubMed]

26. Kabagambe, E.K.; Tsai, M.Y.; Hopkins, P.N.; Ordovas, J.M.; Peacock, J.M.; Borecki, I.B.; Arnett, D.K. Erythrocyte fatty acid composition and the metabolic syndrome: A national heart, lung, and blood institute goldn study. Clin. Chem. 2008, 54, 154. [CrossRef]

27. Damsgaard, C.T.; Stark, K.D.; Hjorth, M.F.; Biltoft-Jensen, A.; Astrup, A.; Michaelsen, K.F.; Lauritzen, L. N-3 pufa status in school children is associated with beneficial lipid profile, reduced physical activity and increased blood pressure in boys. Br. J. Nutr. 2013, 110, 1304-1312. [CrossRef] 
28. Kurotani, K.; Sato, M.; Ejima, Y.; Nanri, A.; Yi, S.; Pham, N.M.; Akter, S.; Poudel-Tandukar, K.; Kimura, Y.; Imaizumi, K.; et al. High levels of stearic acid, palmitoleic acid, and dihomo-gamma-linolenic acid and low levels of linoleic acid in serum cholesterol ester are associated with high insulin resistance. Nutr. Res. 2012, 32, 669-675.e3. [CrossRef]

29. Schiller, K.; Jacobs, S.; Jansen, E.; Weikert, C.; di Giuseppe, R.; Boeing, H.; Schulze, M.B.; Kroger, J. Associated factors of estimated desaturase activity in the epic-potsdam study. NMCD 2014, 24, 503-510. [CrossRef]

30. Cunnane, S.C. Modulation of long chain fatty acid unsaturation by dietary copper. Adv. Exp. Med. Biol. 1989, 258, 183-195.

31. Eder, K.; Kirchgessner, M. The effect of dietary fat on activities of lipogenic enzymes in liver and adipose tissue of zinc-adequate and zinc-deficient rats. J. Nutr. Biochem. 1996, 7, 190-195. [CrossRef]

32. Reed, S.; Qin, X.; Ran-Ressler, R.; Brenna, J.T.; Glahn, R.P.; Tako, E. Dietary zinc deficiency affects blood linoleic acid: Dihomo- $\gamma$-linolenic acid (LA:DGLA) ratio; a sensitive physiological marker of zinc status in vivo (Gallus Gallus). Nutrients 2014, 6, 1164-1180. [CrossRef]

33. Knez, M.; Stangoulis, J.C.R.; Zec, M.; Debeljak-Martacic, J.; Pavlovic, Z.; Gurinovic, M.; Glibetic, M. An initial evaluation of newly proposed biomarker of zinc status in humans-linoleic acid: Dihomo- $\gamma$-linolenic acid (LA:DGLA) ratio. Clin. Nutr. ESPEN 2016, 15, 85-92. [CrossRef] [PubMed]

34. Knez, M.; Stangoulis, J.C.R.; Glibetic, M.; Tako, E. The linoleic acid: Dihomo- $\gamma$-linolenic acid ratio (la:Dgla)-an emerging biomarker of zn status. Nutrients 2017, 9, 825. [CrossRef] [PubMed]

35. Chimhashu, T.; Malan, L.; Baumgartner, J.; van Jaarsveld, P.J.; Galetti, V.; Moretti, D.; Smuts, C.M.; Zimmermann, M.B. Sensitivity of fatty acid desaturation and elongation to plasma zinc concentration: A randomised controlled trial in beninese children. Br. J. Nutr. 2018, 119, 610-619. [CrossRef] [PubMed]

36. Cunnane, S.C. Differential regulation of essential fatty acid metabolism to the prostaglandins: Possible basis for the interaction of zinc and copper in biological systems. Prog. Lipid Res. 1982, 21, 73-90. [CrossRef]

37. Das, U.N. A defect in the activity of delta 6 and delta 5 desaturases may be a factor predisposing to the development of insulin resistance syndrome. Prostaglandins Leukot. Essent. Fatty Acids 2005, 72, 343-350. [CrossRef] [PubMed]

38. Yary, T.; Voutilainen, S.; Tuomainen, T.P.; Ruusunen, A.; Nurmi, T.; Virtanen, J.K. Serum n-6 polyunsaturated fatty acids, delta5- and delta6-desaturase activities, and risk of incident type 2 diabetes in men: The kuopio ischaemic heart disease risk factor study. Am. J. Clin. Nutr. 2016, 103, 1337-1343. [CrossRef]

39. Knez, M.; Tako, E.; Glahn, R.P.; Kolba, N.; de Courcy-Ireland, E.; Stangoulis, J.C.R. Linoleic acid:Dihomo- $\gamma$-linolenic acid ratio predicts the efficacy of Zn-biofortified wheat in chicken (Gallus Gallus). J. Agric. Food Chem. 2018, 66, 1394-1400. [CrossRef]

40. Expert Panel on Detection, Evaluation, and Treatment of High Blood Cholesterol in Adults. Executive summary of the third report of the national cholesterol education program (ncep) expert panel on detection, evaluation, and treatment of high blood cholesterol in adults (adult treatment panel iii). JAMA 2001, 285, 2486-2497. [CrossRef]

41. World Medical Association. World medical association declaration of Helsinki: Ethical principles for medical research involving human subjects. JAMA 2013, 310, 2191-2194. [CrossRef]

42. Nikolić, M.; Milešević, J.; Zeković, M.; Gurinović, M.; Glibetić, M. The development and validation of food atlas for portion size estimation in the balkan region. Front. Nutr. 2018, 5, 78. [CrossRef]

43. Gavrieli, A.; Naska, A.; Konstantinidi, C.; Berry, R.; Roe, M.; Harvey, L.; Finglas, P.; Glibetic, M.; Gurinovic, M.; Trichopoulou, A. Dietary monitoring tools for risk assessment. EFSA Support. Publ. 2014, 11, 607E. [CrossRef]

44. Gurinović, M.; Milešević, J.; Kadvan, A.; Nikolić, M.; Zeković, M.; Djekić-Ivanković, M.; Dupouy, E.; Finglas, P.; Glibetić, M. Development, features and application of diet assess \& plan (dap) software in supporting public health nutrition research in central eastern european countries (ceec). Food Chem. 2018, 238, 186-194.

45. Gurinovic, M.; Milesevic, J.; Kadvan, A.; Djekic-Ivankovic, M.; Debeljak-Martacic, J.; Takic, M.; Nikolic, M.; Rankovic, S.; Finglas, P.; Glibetic, M. Establishment and advances in the online serbian food and recipe data base harmonized with eurofir standards. Food Chem. 2016, 193, 30-38. [CrossRef] [PubMed]

46. Folch, J.; Lees, M.; Sloane Stanley, G.H. A simple method for the isolation and purification of total lipides from animal tissues. J. Biol. Chem. 1957, 226, 497-509. [PubMed] 
47. Pokimica, B.; Garcia-Conesa, M.T.; Zec, M.; Debeljak-Martacic, J.; Rankovic, S.; Vidovic, N.; Petrovic-Oggiano, G.; Konic-Ristic, A.; Glibetic, M. Chokeberry juice containing polyphenols does not affect cholesterol or blood pressure but modifies the composition of plasma phospholipids fatty acids in individuals at cardiovascular risk. Nutrients 2019, 11, 850. [CrossRef]

48. Veselinovic, M.; Vasiljevic, D.; Vucic, V.; Arsic, A.; Petrovic, S.; Tomic-Lucic, A.; Savic, M.; Zivanovic, S.; Stojic, V.; Jakovljevic, V. Clinical benefits of $n-3$ pufa and -linolenic acid in patients with rheumatoid arthritis. Nutrients 2017, 9, 325. [CrossRef]

49. Burdge, G. Alpha-linolenic acid metabolism in men and women: Nutritional and biological implications. Curr. Opin. Clin. Nutr. Metab. Care 2004, 7, 137-144. [CrossRef]

50. Jian, X.Q. Determination of $\mathrm{Cu}, \mathrm{Zn}, \mathrm{Fe}, \mathrm{Ca}, \mathrm{Mg}$, na and $\mathrm{K}$ in serum flame by atomic absorption spectroscopy. In Varian Instruments at Work's; Varian: Sao Paolo, Brazil, 1990; pp. 1-2.

51. Rükgauer, M.; Klein, J.; Kruse-Jarres, J.D. Reference values for the trace elements copper, manganese, selenium, and zinc in the serum/plasma of children, adolescents, and adults. J. Trace Elem. Med. Biol. 1997, 11, 92-98. [CrossRef]

52. Van den Bosch, G.; Van den Bossche, J.; Wagner, C.; De Schouwer, P.; Van De Vyvere, M.; Neels, H. Determination of iron metabolism-related reference values in a healthy adult population. Clin. Chem. 2001, $47,1465$.

53. Brown, K.H.; Rivera, J.A.; Bhutta, Z.; Gibson, R.S.; King, J.C.; Lonnerdal, B.; Ruel, M.T.; Sandtrom, B.; Wasantwisut, E.; Hotz, C. International zinc nutrition consultative group (izincg) technical document \#1. Assessment of the risk of zinc deficiency in populations and options for its control. Food Nutr. Bull. 2004, 25, S99-S203.

54. Team, R. Rstudio: Integrated Development for R; RStudio, Inc.: Boston, MA, USA, 2015.

55. Institute of Medicine Panel on Micronutrients. Dietary reference intakes for vitamin a, vitamin k, arsenic, boron, chromium, copper, iodine, iron, manganese, molybdenum, nickel, silicon, vanadium, and zinc. In Dietary Reference Intakes for Vitamin A, Vitamin K, Arsenic, Boron, Chromium, Copper, Iodine, Iron, Manganese, Molybdenum, Nickel, Silicon, Vanadium, and Zinc; National Academies Press: Washington, DC, USA, 2001; Copyright 2001 by the National Academy of Sciences.

56. Obeid, O.; Elfakhani, M.; Hlais, S.; Iskandar, M.; Batal, M.; Mouneimne, Y.; Adra, N.; Hwalla, N. Plasma copper, zinc, and selenium levels and correlates with metabolic syndrome components of lebanese adults. Biol. Trace Elem. Res. 2008, 123, 58-65. [CrossRef] [PubMed]

57. Seo, J.A.; Song, S.W.; Han, K.; Lee, K.J.; Kim, H.N. The associations between serum zinc levels and metabolic syndrome in the korean population: Findings from the 2010 Korean national health and nutrition examination survey. PLOS ONE 2014, 9, e105990. [CrossRef] [PubMed]

58. Daradkeh, G. Zinc status among type (2) diabetes mellitus in the state of qatar. Public Health Front. 2014, 3, 4-10. [CrossRef]

59. Sanchez, C.; Lopez-Jurado, M.; Planells, E.; Llopis, J.; Aranda, P. Assessment of iron and zinc intake and related biochemical parameters in an adult mediterranean population from southern spain: Influence of lifestyle factors. J. Nutr. Biochem. 2009, 20, 125-131. [CrossRef]

60. Jain, V.K.; Mohan, G. Serum zinc and copper in myocardial infarction with particular reference to prognosis. Biol. Trace Elem. Res. 1991, 31, 317-322. [CrossRef]

61. Yu, Y.; Cai, Z.; Zheng, J.; Chen, J.; Zhang, X.; Huang, X.F.; Li, D. Serum levels of polyunsaturated fatty acids are low in chinese men with metabolic syndrome, whereas serum levels of saturated fatty acids, zinc, and magnesium are high. Nutr. Res. 2012, 32,71-77. [CrossRef]

62. Chang, S.; El Arifeen, S.; Bari, S.; Wahed, M.A.; Rahman, K.M.; Rahman, M.T.; Mahmud, A.B.; Begum, N.; Zaman, K.; Baqui, A.H.; et al. Supplementing iron and zinc: Double blind, randomized evaluation of separate or combined delivery. Eur. J. Clin. Nutr. 2010, 64, 153-160. [CrossRef]

63. Knez, M.; Graham, R.D.; Welch, R.M.; Stangoulis, J.C.R. New perspectives on the regulation of iron absorption via cellular zinc concentrations in humans. Crit. Rev. Food Sci. Nutr. 2017, 57, 2128-2143. [CrossRef]

64. Knez, M.; Nikolic, M.; Zekovic, M.; Stangoulis, J.C.R.; Gurinovic, M.; Glibetic, M. The influence of food consumption and socio-economic factors on the relationship between zinc and iron intake and status in a healthy population. Pub. Health Nut. 2017, 20, 2486-2498. [CrossRef] 
65. Bárány, E.; Bergdahl, I.A.; Bratteby, L.E.; Lundh, T.; Samuelson, G.; Schütz, A.; Skerfving, S.; Oskarsson, A. Relationships between trace element concentrations in human blood and serum. Toxicol. Lett. 2002, 134, 177-184. [CrossRef]

66. Grungreiff, K.; Reinhold, D.; Wedemeyer, H. The role of zinc in liver cirrhosis. Ann. Hept. 2016, 15, 7-16. [CrossRef] [PubMed]

67. Florianczyk, B. Copper in the organism-Transport and storage in the cells. Ann. Univ. Mariae Curie-Sklodowska Sectio D Med. 2003, 58, 85-88.

68. Malavolta, M.; Piacenza, F.; Basso, A.; Giacconi, R.; Costarelli, L.; Mocchegiani, E. Serum copper to zinc ratio: Relationship with aging and health status. Mech. Ageing Dev. 2015, 151, 93-100. [CrossRef] [PubMed]

69. Klevay, L.M. Coronary heart disease: The zinc/copper hypothesis. Am. J. Clin. Nutr. 1975, 28, 764-774. [CrossRef]

70. Bialkowska, M.; Hoser, A.; Szostak, W.B.; Dybczynski, R.; Sterlinski, S.; Nowicka, G.; Majchrzak, J.; Kaczorowski, J.; Danko, B. Hair zinc and copper concentration in survivors of myocardial infarction. Ann Nutr. Metab. 1987, 31, 327-332.

71. Bonaventura, P.; Benedetti, G.; Albarede, F.; Miossec, P. Zinc and its role in immunity and inflammation. Autoimmun. Rev. 2015, 14, 277-285. [CrossRef]

72. Malavolta, M.; Giacconi, R.; Piacenza, F.; Santarelli, L.; Cipriano, C.; Costarelli, L.; Tesei, S.; Pierpaoli, S.; Basso, A.; Galeazzi, R.; et al. Plasma copper/zinc ratio: An inflammatory/nutritional biomarker as predictor of all-cause mortality in elderly population. Biogerontology 2010, 11, 309-319. [CrossRef]

73. Arnaud, J.; Faure, H.; Bourlard, P.; Denis, B.; Favier, A.E. Longitudinal changes in serum zinc concentration and distribution after acute myocardial infarction. Clin. Chim. Acta Int. J. Clin. Chem. 1994, 230, 147-156. [CrossRef]

74. Bailey, A.L.; Maisey, S.; Southon, S.; Wright, A.J.; Finglas, P.M.; Fulcher, R.A. Relationships between micronutrient intake and biochemical indicators of nutrient adequacy in a 'free-living' elderly UK population. Br. J. Nutr. 1997, 77, 225-242. [CrossRef]

75. Gibson, R.S. Zinc: The missing link in combating micronutrient malnutrition in developing countries. Proc. Nutr. Soc. 2006, 65, 51-60. [CrossRef]

76. Coulibaly, A.; Kouakou, B.; Chen, J. Phytic acid in cereal grains: Structure, healthy or harmful ways to reduce phytic acid in cereal grains and their effects on nutritional quality. Am. J. Plant Nutr. Fertil. Tech. 2011, 1, 1-22. [CrossRef]

77. Jati, I.R.; Widmer, C.; Purwestri, R.C.; Wirawan, N.N.; Gola, U.; Lambert, C.; Biesalski, H.K. Design and validation of a program to identify inadequate intake of iron, zinc, and vitamin a. Nutrients 2014, 30, 1310-1317. [CrossRef] [PubMed]

78. Chehrei, A.; Sadrnia, S.; Keshteli, A.H.; Daneshmand, M.A.; Rezaei, J. Correlation of dyslipidemia with waist to height ratio, waist circumference, and body mass index in iranian adults. Asia Pac. J. Clin. Nutr. 2007, 16, 248-253. [PubMed]

79. Ghayour-Mobarhan, M.; Taylor, A.; Kazemi-Bajestani, S.M.; Lanham-New, S.; Lamb, D.J.; Vaidya, N.; Livingstone, C.; Wang, T.; Ferns, G.A. Serum zinc and copper status in dyslipidaemic patients with and without established coronary artery disease. Clin. Lab. 2008, 54, 321-329. [PubMed]

80. Romero, C.D.; Sánchez, P.H.; Blanco, F.L.; Rodríguez, E.R.; Majem, L.S. Serum copper and zinc concentrations in a representative sample of the canarian population. J. Trace Elem. Med. Biol. 2002, 16, 75-81. [CrossRef]

81. Villalpando, S.; Garcia-Guerra, A.; Ramirez-Silva, C.I.; Mejia-Rodriguez, F.; Matute, G.; Shamah-Levy, T.; Rivera, J.A. Iron, zinc and iodide status in mexican children under 12 years and women 12-49 years of age. A probabilistic national survey. Salud Publica Mex. 2003, 45 (Suppl. 4), 520-529. [CrossRef]

82. Al-Sabaawy, O.M. The relationship between serum lipid profile and selected trace elements for adult men in mosul city. Oman Med J. 2012, 27, 300-303. [CrossRef]

83. Yerlikaya, F.H.; Toker, A.; Aribas, A. Serum trace elements in obese women with or without diabetes. Indian J. Med. Res. 2013, 137, 339-345.

84. Di Martino, G.; Matera, M.G.; De Martino, B.; Vacca, C.; Di Martino, S.; Rossi, F. Relationship between zinc and obesity. J. Med. 1993, 24, 177-183.

85. Choi, M.K.; Bae, Y.J. Relationship between dietary magnesium, manganese, and copper and metabolic syndrome risk in korean adults: The korea national health and nutrition examination survey (2007-2008). Biol. Trace Elem. Res. 2013, 156, 56-66. [CrossRef] 
86. Selva, D.M.; Lecube, A.; Hernandez, C.; Baena, J.A.; Fort, J.M.; Simo, R. Lower zinc-alpha2-glycoprotein production by adipose tissue and liver in obese patients unrelated to insulin resistance. J. Clin. Endocrinol. Metab. 2009, 94, 4499-4507. [CrossRef] [PubMed]

87. Neggers, Y.; Bindon, J.; Dressler, W. The relationship between zinc and copper status and lipid levels in african-americans. Biol. Trace Elem. Res. 2001, 79, 1-13. [CrossRef]

88. Gunasekara, P.; Hettiarachchi, M.; Liyanage, C.; Lekamwasam, S. Effects of zinc and multimineral vitamin supplementation on glycemic and lipid control in adult diabetes. Diabetes Metab. Syndr. Obes. 2011, 4, 53-60. [PubMed]

89. Lima, S.C.; Arrais, R.F.; Sales, C.H.; Almeida, M.G.; de Sena, K.C.; Oliveira, V.T.; de Andrade, A.S.; Pedrosa, L.F. Assessment of copper and lipid profile in obese children and adolescents. Biol. Trace Elem. Res. 2006, 114, 19-29. [CrossRef]

90. Carpenter, W.E.; Lam, D.; Toney, G.M.; Weintraub, N.L.; Qin, Z. Zinc, copper, and blood pressure: Human population studies. Medical science monitor: International medical journal of experimental and clinical research. Med. Sci. Monit. 2013, 19, 1-8. [CrossRef]

91. Atari-Hajipirloo, S.; Valizadeh, N.; Khadem-Ansari, M.-H.; Rasmi, Y.; Kheradmand, F. Altered concentrations of copper, zinc, and iron are associated with increased levels of glycated hemoglobin in patients with type 2 diabetes mellitus and their first-degree relatives. Int. J. Endocrinol. Metab. 2016, 14, e33273. [CrossRef]

92. Tubek, S. Role of zinc in regulation of arterial blood pressure and in the etiopathogenesis of arterial hypertension. Biol. Trace Elem. Res. 2007, 117, 39-51. [CrossRef]

93. Hennig, B.; Toborek, M.; McClain, C.J. High-energy diets, fatty acids and endothelial cell function: Implications for atherosclerosis. J. Am. Coll. Nutr. 2001, 20, 97-105. [CrossRef]

94. Paillard, F.; Catheline, D.; Duff, F.L.; Bouriel, M.; Deugnier, Y.; Pouchard, M.; Daubert, J.C.; Legrand, P. Plasma palmitoleic acid, a product of stearoyl-coA desaturase activity, is an independent marker of triglyceridemia and abdominal adiposity. Nutr. Metab. Cardiovasc. Dis. 2008, 18, 436-440. [CrossRef]

95. Warensjo, E.; Rosell, M.; Hellenius, M.L.; Vessby, B.; De Faire, U.; Riserus, U. Associations between estimated fatty acid desaturase activities in serum lipids and adipose tissue in humans: Links to obesity and insulin resistance. Lipids Health Dis. 2009, 8, 37. [CrossRef]

96. Do, H.J.; Chung, H.K.; Moon, J.; Shin, M.J. Relationship between the estimates of desaturase activities and cardiometabolic phenotypes in koreans. J. Clin. Biochem. Nutr. 2011, 49, 131-135. [PubMed]

97. Kathiresan, S.; Willer, C.J.; Peloso, G.M.; Demissie, S.; Musunuru, K.; Schadt, E.E.; Kaplan, L.; Bennett, D.; Li, Y.; Tanaka, T.; et al. Common variants at 30 loci contribute to polygenic dyslipidemia. Nat. Genet. 2009, 41, 56-65. [CrossRef] [PubMed]

98. Chilton, F.H.; Murphy, R.C.; Wilson, B.A.; Sergeant, S.; Ainsworth, H.; Seeds, M.C.; Mathias, R.A. Diet-gene interactions and pufa metabolism: A potential contributor to health disparities and human diseases. Nutrients 2014, 6, 1993-2022. [CrossRef] [PubMed]

99. Cunnane, S.C. Iron, copper, zinc and selenium: The other brain selective minerals. In Survival of the Fattest; World Scientific Publishing Company: Singapore, 2005; pp. 131-150.

100. Krishnamurthy, P.; Wadhwani, A. Antioxidant Enzymes and Human Health. Available online: https: //www.intechopen.com/books/antioxidant-enzyme/antioxidant-enzymes-and-human-health (accessed on 27 December 2019).

101. Fan, Y.; Zhang, C.; Bu, J. Relationship between selected serum metallic elements and obesity in children and adolescent in the U.S. Nutrients 2017, 9, 104. [CrossRef]

102. Wahle, E.W.; Davies, N.T. Effect of dietary copper deficiency. In the rat on fatty acid composition of adipose tissue and desaturase activity of liver microsomes. Br. J. Nutr. 1975, 34, 105-112. [CrossRef]

103. Ho, S.K.; Elliot, J.I.; Jones, G.M. Effects of copper on performance, fatty acid composition of depot fat and fatty acyl desaturase activities in pigs fed a diet with or without supplemental copper. Can. J. Anim. Sci. 1975, 55, 587-594. [CrossRef]

104. Bradbury, K.E.; Skeaff, C.M.; Crowe, F.L.; Green, T.J.; Hodson, L. Serum fatty acid reference ranges: Percentiles from a new zealand national nutrition survey. Nutrients 2011, 3, 152-163. [CrossRef]

105. Rasic-Milutinovic, Z.; Popovic, T.; Perunicic-Pekovic, G.; Arsic, A.; Borozan, S.; Glibetic, M. Lower serum paraoxonase- 1 activity is related to linoleic and docosahexanoic fatty acids in type 2 diabetic patients. Arch. Med. Res. 2012, 43, 75-82. [CrossRef] 
106. Wang, Y.; Huang, F. N-3 polyunsaturated fatty acids and inflammation in obesity: Local effect and systemic benefit. BioMed. Res. Int. 2015, 2015, 581469. [CrossRef]

107. Cha, S.H.; Fukushima, A.; Sakuma, K.; Kagawa, Y. Chronic docosahexaenoic acid intake enhances expression of the gene for uncoupling protein 3 and affects pleiotropic mrna levels in skeletal muscle of aged c57bl/6njcl mice. J. Nutr. 2001, 131, 2636-2642. [CrossRef]

108. Oliver, E.; McGillicuddy, F.; Phillips, C.; Toomey, S.; Roche, H.M. The role of inflammation and macrophage accumulation in the development of obesity-induced type 2 diabetes mellitus and the possible therapeutic effects of long-chain n-3 pufa. Proc. Nutr. Soc. 2010, 69, 232-243. [CrossRef] [PubMed]

109. Jackson, K.H.; Harris, W.S. Blood fatty acid profiles: New biomarkers for cardiometabolic disease risk. Curr. Atheroscler. Rep. 2018, 20, 22. [CrossRef] [PubMed]

110. Sanders, T.A.; Gleason, K.; Griffin, B.; Miller, G.J. Influence of an algal triacylglycerol containing docosahexaenoic acid (22:6 n-3) and docosapentaenoic acid (22:5n-6) on cardiovascular risk factors in healthy men and women. Br. J. Nutr. 2006, 95, 525-531. [CrossRef] [PubMed]

111. Ramakers, J.D.; Mensink, R.P.; Schaart, G.; Plat, J. Arachidonic acid but not eicosapentaenoic acid (epa) and oleic acid activates nf-kappab and elevates icam-1 expression in caco-2 cells. Lipids 2007, 42, 687-698. [CrossRef]

112. Arkan, M.C.; Hevener, A.L.; Greten, F.R.; Maeda, S.; Li, Z.W.; Long, J.M.; Wynshaw-Boris, A.; Poli, G.; Olefsky, J.; Karin, M. Ikk-beta links inflammation to obesity-induced insulin resistance. Nat. Med. 2005, 11, 191-198. [CrossRef]

113. Simopoulos, A.P. The omega-6/omega-3 fatty acid ratio: Health implications. OCL 2010, 17, $267-275$. [CrossRef]

114. Simopoulos, A.P. The importance of the omega-6/omega-3 fatty acid ratio in cardiovascular disease and other chronic diseases. Exp. Biol. Med. 2008, 233, 674-688. [CrossRef]

115. Esrey, K.L.; Joseph, L.; Grover, S.A. Relationship between dietary intake and coronary heart disease mortality: Lipid research clinics prevalence follow-up study. J. Clin. Epidemiol. 1996, 49, 211-216. [CrossRef]

116. Boniface, D.R.; Tefft, M.E. Dietary fats and 16-year coronary heart disease mortality in a cohort of men and women in great britain. Eur. J. Clin. Nutr. 2002, 56, 786-792. [CrossRef]

117. Peter, A.; Cegan, A.; Wagner, S.; Lehmann, R.; Stefan, N.; Konigsrainer, A.; Konigsrainer, I.; Haring, H.U.; Schleicher, E. Hepatic lipid composition and stearoyl-coenzyme a desaturase 1 mrna expression can be estimated from plasma vldl fatty acid ratios. Clin. Chem. 2009, 55, 2113-2120. [CrossRef] 